\title{
Structurally Different Neuronal Nicotinic Acetylcholine Receptor Subtypes Purified and Characterized Using Monoclonal Antibodies
}

\author{
Paul J. Whiting, ${ }^{1}$ RuShya Liu, ${ }^{1}$ Barbara J. Morley, ${ }^{2}$ and Jon M. Lindstrom ${ }^{1}$ \\ ${ }^{1}$ The Salk Institute for Biological Studies, San Diego, California 92138, and ${ }^{2}$ Boys Town National Institute for \\ Communication Disorders in Children, Omaha, Nebraska 68131
}

\begin{abstract}
Acetylcholine receptors that bind nicotine with high affinity but do not bind $\alpha$-abungarotoxin have recently been immunoaffinity purified from brains of chickens and rats (Whiting and Lindstrom, 1986a, b; Whiting and Lindstrom, 1987a). Antisera to these receptors bind to the nicotinic receptors that regulate cation channel opening on chick ciliary ganglion neurons (Stollberg et al., 1986) and rat PC12 cells (Whiting et al., 1987c). Here we report the preparation and characterization of monoclonal antibodies to chicken brain acetylcholine receptors. These monoclonal antibodies are used to identify 2 nicotinic receptor subtypes in the chicken brain. The 2 subtypes have very similar affinities for nicotine and other cholinergic agonists and antagonists. However, they are structurally distinct, having very similar or identical $\alpha$ subunits $\left(M_{\mathrm{r}} 49,000\right)$, but different $\beta$ subunits $\left(M_{\mathrm{r}} 59,000\right.$, or for $\beta^{\prime}$ subunit, $M_{r} 75,000$ ). Evidence is presented that suggests that the subunit stoichiometry of these neuronal nicotinic acetylcholine receptors is $\alpha_{n=2-3} \beta_{n=2-3}$. Different levels of receptor subtype expression were detected in embryonic, compared to adult, chicken brain.
\end{abstract}

The nicotinic acetylcholine receptors (AChRs) from both electric organ and skeletal muscle have been purified and extensively characterized, in large part because of 2 gifts of nature: fish electric organs and snake toxins (for reviews, see Popot and Changeux, 1984, and McCarthy et al., 1986). Electric organs provide a rich source of $\mathrm{AChR}$, and $\alpha$-bungarotoxin ( $\alpha \mathrm{Bgt}$ ) provides a biochemical probe with very high affinity for the ACh binding site of these AChRs. Monoclonal antibodies (mAbs) have proven to be equally powerful tools for studying AChRs, providing valuable information on $\mathrm{AChR}$ structure, function, biosynthesis, development, and autoimmune response (for reviews, see Lindstrom, 1984, 1986a, b).

By contrast, nicotinic AChRs in the central nervous system have remained far more elusive for lack of comparable gifts of nature. Very small amounts of AChR are present in brain. Neuronal bungarotoxin is a component of Bungarus multicinctus

\footnotetext{
Received Jan. 29, 1987; revised June 8, 1987; accepted June 8, 1987

We wish to thank John Cooper and Michael Lin for technical help. This work was supported by grants to J.L. from the National Institutes of Health (NS11323), the Muscular Dystrophy Association, the Alexander S. Onassis Public Benefit Foundation, the Los Angeles and California Chapters of the Myasthenia Gravis Foundation, and the U.S. Army (DAMD17-86-C-6148). P.W. was supported by the Muscular Dystrophy Association Carl M. Pearson Postdoctoral Fellowship. B.J.M. was supported in part by NSF Grant BNS-8410198.

Correspondence should be addressed to Dr. Jon M. Lindstrom, The Salk Institute for Biological Studies, P.O. Box 85800, San Diego, CA 92138.

Copyright (C) 1987 Society for Neuroscience $0270-6474 / 87 / 124005-12 \$ 02.00 / 0$
}

venom, which, unlike $\alpha$ Bgt, binds to neuronal nicotinic AChRs. However, neuronal bungarotoxin is present in smaller amounts than $\alpha$ Byt, has lower aflinity and specificity, and has only recently been ${ }^{125}$ I-labeled (Chiapinelli, 1983, 1985; Halvorsen and Berg, 1986, 1987; Smith et al., 1986; Chiapinelli et al., 1987). The absence of suitable biochemical probes has recently been compensated for by technical advances in the form of $\mathrm{mAb}$ probes (Whiting and Lindstrom, 1986a, b, 1987a, b) and cDNA probes (Boulter et al., 1986; Goldman et al., 1986, 1987).

Although $\alpha$ Bgt binding sites are found in the nervous system, their physiological role is unclear. $\alpha$ Bgt blocks neuronal AChR function in the cockroach (Sattelle et al., 1983), toad, and goldfish (Freeman et al., 1980), but has no effect on AChRs in rat cervical ganglion (Brown and Fumagalli, 1977), rat PC12 cells (Patrick and Stallcup, 1977), chick ciliary ganglion neurons (Carbonetto et al., 1978; Kouvelas et al., 1978; Ravdin and Berg, 1979; Chiappinelli, 1983), or cat carotid bodies (Gonzales et al., 1986). The $\alpha$ Bgt binding protein has been purified from brains of chickens (Conti-Tronconi et al., 1985) and rats (Kemp and Morley, 1986; Whiting and Lindstrom, 1987a). The aminoterminal amino acid sequence homology of one of its subunits with the subunits of muscle AChR (Conti-Tronconi et al., 1985) indicates that it is a member of the nicotinic AChR gene family.

While searching for useful $\mathrm{mAb}$ probes for neuronal $\mathrm{AChRs}$, we found that $\mathrm{mAb} 35$, raised against $\mathrm{AChRs}$ from electric organ (Tzartos et al., 1981), specifically binds cells in the lateral spiriform nucleus and optic tectum of chick brains (Swanson et al., 1983). mAb 35 also binds to synaptic sites on chick ciliary ganglion cells (Jacob et al., 1984, 1986). By contrast, $\alpha$ Bgt binds to extrasynaptic regions on these cells (Jacob and Berg, 1983). The ganglionic component that binds $\mathrm{mAb} 35$ has the biochemical properties expected of an AChR (Smith et al., 1985), its amount can be modulated by cholinergic ligands (Smith et al., 1986), and it binds a neuronal bungarotoxin that blocks neuronal AChR function (Halvorsen and Berg, 1987).

Using $\mathrm{mAb} 35$, we subsequently purified an $A C h R$ from chicken brain by immunoaffinity chromatography (Whiting and Lindstrom, 1986a). This AChR is an integral membrane glycoprotein approximately $10 \mathrm{~S}$ in size with 2 subunits: $\alpha$ (M $M_{\mathrm{r}}$ $49,000)$ and $\beta\left(M_{\mathrm{r}} 59,000\right)$. The $\alpha$ subunit binds both antisera and a $\mathrm{mAb}(210)$ specific for a $\alpha$ subunits of AChRs from electric organ and skeletal muscle. This AChR reversibly binds nicotinic ligands, but does not bind $\alpha \mathrm{Bgt}$, and it can be affinity-labeled with bromoacetylcholine (BAC) and 4-( $N$-maleimido)benzyltrimethylammonium iodide (MBTA) (Whiting and Lindstrom, 1986b, 1987b). Antisera raised in rats against the $\mathrm{AChR}$ from chicken brain specifically block the $\mathrm{ACh}$-induced 
depolarization of chick ciliary ganglion cells in culture (Stollberg et al., 1986), showing that the antibodies bind to a physiologically significant AChR.

However, $\mathrm{mAb} 35$ binds only negligibly to nicotinic AChRs from the brains of rats (Whiting and Lindstrom, 1986b) and thus cannot be used for their purification and characterization. In addition, we only had one subunit-specific mAb (mAb 210) that cross-reacted with AChRs from chicken brains. Thus, mAbs were prepared to AChRs from chicken brains with the aim of producing additional biochemical probes to AChRs from chicken brain, and probes that would also allow the location, purification, and characterization of homologous AChRs from rat brain. These aims have been achieved (Whiting and Lindstrom, 1986b, 1987a, b; Swanson et al., 1987; Whiting et al., 1987a, b).

Here we report the production and characterization of subunit-specific mAbs to $\mathrm{AChRs}$ from chicken brain, and use these mAbs to demonstrate homologies between AChR subunits, to investigate the stoichiometries of subunits in the AChR macromolecule, and to discover the existence of structurally distinct AChR subtypes in chicken brains.

\section{Materials and Methods}

AChR purification. AChRs from chicken brain were purified by immunoaffinity chromatography using mAb 35 or mAb 270 coupled to Sepharose CL4B (at 10 or $8 \mathrm{mg} / \mathrm{ml}$, respectively), as previously described (Whiting and Lindstrom, 1986a, 1987a). Purified AChR was radioiodinated essentially as described previously (Whiting and Lindstrom, 1986a). Briefly, AChR from 100 brains (obtained from Pel-Freez Biologicals) was purified through 2 rounds of immunoaffinity chromatography, eluted from the second-antibody column in a pH 3.0 buffer containing $0.05 \%$ Tween-20 detergent, and then concentrated and desalted to a final volume of approximately $100 \mu \mathrm{l}$ using a Centricon 30 (Amicon) microconcentrator. The purified AChR, 5-10 pmol, was then radioiodinated using the lactoperoxidase-glucose oxidase method (BioRad), and kept at $4^{\circ} \mathrm{C}$ in $10 \mathrm{~mm}$ Na phosphate, pH $7.5,100 \mathrm{~mm}$ $\mathrm{NaCl}$ (PBS) containing $0.5 \%$ Triton $\mathrm{X}-100,10 \mathrm{~mm}$ sodium azide, and $10 \mathrm{mg} / \mathrm{ml} \beta$-lactoglobulin.

Detergent extracts of Torpedo, rat, bovine and human brains, and chick muscle were also prepared as previously described (Whiting and Lindstrom, 1986a). Human brain was obtained through the courtesy of Dr. Robert Terry. AChR from Torpedo electric organ was affinity-purified by standard techniques (Lindstrom et al., 1981).

Immunization and fusions. Female Lewis rats (6-8 weeks old) received intramuscular injections of purified chicken brain AChR, both intact and SDS-denatured, emulsified in 100-200 $\mu$ lof complete Freund's adjuvant (CFA). Dctails of the immunization schcdulcs are given in Table 1. The rats were killed and their spleen cells fused with the mouse myeloma cell line S194 15.XXO.BU.1, using 50\% polyethylene glycol 4000 (Merck) as described in detail elsewhere (Hochschwender et al., 1985). Culture supernatants were initially screened by solid-phase immunoassay using immobilized affinity-purified AChR from chicken brain (Whiting and Lindstrom, 1986a). Hybridoma supernatants, which were positive in this assay, and which, upon rescreening, exhibited binding to AChRs labeled with ${ }^{3} \mathrm{H}$-nicotine in detergent extracts of chicken brain (see below) and/or binding to subunits on western blots of purified AChR from chicken brain, were selected for recloning. Hybridoma cells were cloned directly in agarose (Hochschwender et al., 1985) and then grown in bulk in Iscove's medium containing $1 \%$ fetal calf serum. Supernatants from mass cultures were concentrated to about $300 \mathrm{ml}$ using a Millipore Minitan concentrator, and the immunoglobulin fraction isolated by precipitation with $18 \%$ sodium sulfate and then dialyzed against PBS containing $10 \mathrm{mM} \mathrm{NaN}_{3}$. Immunoglobulin class and subclass were determined by the Ouchterlony technique using anti-rat immunoglobulin subclass antisera (Miles). $\mathrm{mAb} 270$ was purified as previously described (Whiting and Lindstrom, 1987a), and mAb 285 was purified by highperformance liquid chromatography (HPLC) on a hydroxylapatite column (BioRad).

Antibody-binding assays. 1. Solid-phase immunoassay: Cell culture supernatants were screened by solid-phase immunoassay (Whiting and
Lindstrom, 1986a). Briefiy, affinity-purified AChR from chicken brain (10-100 fmol quantitated in terms of ${ }^{125}$ I-mAb 35 binding sites) in 30 $\mu \mathrm{l}$ of PBS was applied to Millipore Millititer 96-well nitrocellulose plates and incubated overnight at $4^{\circ} \mathrm{C}$. The plates were quenched for $30 \mathrm{~min}$ at room temperature with $50 \mu 1$ of PBS containing $1 \%$ bovine serum albumin and $0.2 \%$ Tween-20 (quench buffer), and then $100 \mu$ l of culture supernatant was added, followed by overnight incubation at $4^{\circ} \mathrm{C}$. Plates were then washed twice with $300 \mu$ lof quench buffer and incubated for $2 \mathrm{hr}$ at room temperature with $10 \mathrm{nM}{ }^{125}$ I-goat anti-rat IgG $\left(2-3 \times 10^{-18}\right.$ $\mathrm{cpm} / \mathrm{mol}$ ). After 2 further washes, the nitrocellulose disks were punched out, and bound radioactivity determined by gamma counting. Nonspecific binding was determined by incubation with control culture supernatant.

2. ${ }^{3} \mathrm{H}$-nicotine binding assay: Antibody binding to AChRs in crude detergent extracts of brain was determined as described previously (Whiting and Lindstrom, 1986b). Briefly, detergent extract (200-500 $\mu \mathrm{l}$ ) was shaken gently for $15 \mathrm{hr}$ at $4^{\circ} \mathrm{C}$ with $100 \mu$ l of culture supernatant, diluted $\mathrm{mAb}$, or serum, and $20-30 \mu \mathrm{l}$ of a 1:1 slurry of goat anti-rat IgG Sepharose (8-12.5 $\mathrm{mg} \mathrm{IgG/ml} \mathrm{gel).} \mathrm{After} \mathrm{washing} \mathrm{twice} \mathrm{with} 1 \mathrm{ml}$ of PBS containing $0.5 \%$ Triton $\mathrm{X}-100$, the aliquots were incubated for $15 \mathrm{~min}$ at room temperature in $20 \mathrm{nM}{ }^{3} \mathrm{H}$-nicotine $\mathrm{DL}-\mathrm{N}$-methyl ${ }^{3} \mathrm{H}$ nicotine, sp act $68.6 \mathrm{Ci} / \mathrm{mmol}$, (obtained from NEN) in the same buffer, and then washed rapidly 4 times at $4^{\circ} \mathrm{C}$ with $1 \mathrm{ml}$ of ice-cold $\mathrm{PBS}, 0.5 \%$ Triton X-100 by resuspending in the buffer and centrifuging for $20 \mathrm{sec}$ at $10,000 \times g$ in a microfuge. Bound protein was then eluted by incubating the gel for $15 \mathrm{~min}$ with $100 \mu \mathrm{l}$ of $2.5 \% \mathrm{SDS}, 5 \% \beta$-mercaptoethanol, and then sampling into $5 \mathrm{ml}$ of scintillant $5 \%$ Biosolve (Beckman), 4\% Liquifluor (NEN) in toluene]. Radioactivity was determined by scintillation counting. Specific binding was determined by the subtraction of binding in the absence of antibody.

Polyacrylamide gel electrophoresis and western blot analysis. SDSPAGE and western blotting of protein samples were performed as previously described (Whiting and Lindstrom, 1986a), with the exception that when probing western blots with antibodies, all incubations were carried out in PBS, $0.5 \%$ Triton X-100 buffer, which contained $5 \%$ (wt/ vol) milk powder (Carnation) rather than bovine serum albumin.

\section{Results}

Making a library of $m A$ bs to AChRs from chick brain

A library of $8 \mathrm{mAbs}$ to nicotinic AChRs from chicken brain was prepared from rats immunized with AChRs imunoaffinitypurified using $\mathrm{mAb} 35$. The preparation and properties of these mAbs is shown in Table 1. For reference, properties of mAbs 35 and 210 to $A C h R s$ from eel electric organ and mammalian muscle that were used in these studies are also listed in Table 1.

\section{Discovery of subtypes of chicken brain AChRs}

$\mathrm{mAb} 270$ cross-reacted with homologous nicotinic AChRs from brains of rats (Whiting and Lindstrom, 1986b). This $\mathrm{mAb}$ was coupled to Sepharose CL4B and used to immunoaffinity-purify these AChRs from rat brain (Whiting and Lindstrom, 1987a). AChR from rat brain contains 2 types of subunits, $M_{\mathrm{r}} 51,000$ $(\alpha)$ and $79,000(\beta)$. The smaller subunit is homologous to the 49,000 $M_{\mathrm{r}}$ subunit of AChRs from chicken brain, since both bind antisera to $\alpha$ subunits of AChR from Torpedo electric organ and $\mathrm{mAbs} 268$ and 270 (Whiting and Lindstrom, 1987a; see also Fig. 2). The larger subunit $\left(M_{\mathrm{r}} 79,000\right)$ of the AChR from rat brain is considerably larger than the $\beta$ subunit $\left(M_{\mathrm{r}} 59,000\right)$ of AChR from chicken brain. This suggested that the AChRs we had purified from rat brain using mAb 270 were not strictly homologous to the AChRs purified from chicken brain using $\mathrm{mAb} 35$.

To further investigate this observation, $\mathrm{mAb} 270$, coupled to Sepharose, was used to immunoaffinity-purify AChRs from chicken brain. Analysis of the purified AChR by SDS-PAGE and subsequent silver-staining led to the surprising finding of 2 subunits of the same $M_{\mathrm{r}}$ as the subunits of AChR purified from chicken brain on mAb 35 Sepharose $\left(M_{\mathrm{r}} 49,000\right.$ and 59,000; 
Table 1. Properties of mAbs to chicken brain nicotinic AChRs

\begin{tabular}{|c|c|c|c|c|c|c|c|c|c|}
\hline \multirow[b]{3}{*}{$\mathrm{mAb}$} & \multirow[b]{3}{*}{ Immunization schedule ${ }^{a}$} & \multirow[b]{3}{*}{ Ig class ${ }^{h}$} & \multicolumn{5}{|c|}{ Titer $(\mu \mathrm{M})$ to $\mathrm{AChRs}$ from: } & \multirow{3}{*}{$\begin{array}{l}\text { Sub- } \\
\text { unit } \\
\text { speci- } \\
\text { ficity }\end{array}$} & \multirow{3}{*}{$\begin{array}{l}\text { AChR } \\
\text { subtype } \\
\text { speci- } \\
\text { ficity }\end{array}$} \\
\hline & & & \multirow{2}{*}{$\begin{array}{l}\text { Torpedo } \\
\text { electric } \\
\text { organ }^{c}\end{array}$} & \multicolumn{4}{|l|}{ Brains $^{\alpha}$} & & \\
\hline & & & & Chicken & Rat & $\begin{array}{l}\text { Fetal } \\
\text { calf }\end{array}$ & Human & & \\
\hline $35^{\prime}$ & Electric organ $\mathrm{AChR}$ & IgG1 & 28.5 & 0.33 & 0 & 0 & 0 & $\alpha^{g}$ & $\alpha \beta$ \\
\hline $210^{\prime}$ & Muscle AChR & $\operatorname{IgG} 1$ & 31.3 & 0.39 & 0 & 0 & 0 & $\alpha^{g}$ & $\alpha \beta / \alpha \beta^{\prime}$ \\
\hline & Chicken brain AChR & & & & & & & & \\
\hline 267 & A & $\operatorname{IgG} 2 \mathrm{a}$ & 0 & 0 & 0 & 0 & 0 & $\alpha, \beta$ & $\alpha \beta / \alpha \beta^{\prime}$ \\
\hline 268 & $\mathrm{~A}$ & $\operatorname{IgGl} 1 / 2 \mathrm{a}^{b}$ & 0 & 0 & 0 & 0 & 0 & $\alpha$ & $\alpha \beta / \alpha \beta^{\prime}$ \\
\hline 270 & B & $\operatorname{IgG} 2 \mathrm{a}$ & 0 & 1.10 & 0.18 & 0 & 0 & $\alpha$ & $\alpha \beta / \alpha \beta^{\prime}$ \\
\hline 284 & $\mathrm{C}$ & $\operatorname{IgG} 2 \mathrm{a}$ & 0 & 2.00 & 0 & 0 & 0 & $\beta^{\prime}$ & $\alpha \beta^{\prime}$ \\
\hline 285 & $\mathrm{C}$ & $\operatorname{IgG} 2 \mathrm{a}$ & 0.014 & 1.40 & 0 & 0 & 0 & $\beta^{\prime}$ & $\alpha \beta^{\prime}$ \\
\hline 286 & $\mathrm{C}$ & IgM & 0 & 0.64 & 0.45 & 0 & 0.13 & $\beta^{\prime}(\alpha)$ & $\alpha \beta / \alpha \beta^{\prime}$ \\
\hline 287 & $\mathrm{C}$ & IgM & 0 & 0 & 0 & 0 & 0 & $\alpha$ & $\alpha \beta / \alpha \beta^{\prime}$ \\
\hline 289 & $\mathrm{D}$ & IgM & 0 & 0.18 & 0 & 0 & 0 & $\beta^{\prime}$ & $\alpha \beta^{\prime}$ \\
\hline
\end{tabular}

${ }^{\circ} \mathrm{A}$, Lewis rats were injected on days $0,26,39,57$, and 75 with $10,30,30,20$, and 12 pmol of SDS-denatured chicken brain AChR in CFA, and on days 81,82 , and 83 with 21,21 , and 9 pmol AChR in PBS, and then killed on day 85 . B, Lewis rats were injected on days $0,18,32,62$, and 84 with $20,12,22,21$, and 21 pmol of SDS-denatured chicken brain AChR in CFA and on days 94, 95, and 96 with $10 \mathrm{pmol}$ of AChR in PBS, and then killed on day 98. C, Lewis rats were injected on days 0,21 , and 42 , with 15,22 , and $15 \mathrm{pmol}$ of chicken brain AChR $(50 \%$ of which had been denatured in SDS) in CFA, and then on day 70 with $32 \mathrm{pmol} \mathrm{AChR} \mathrm{in} \mathrm{PBS,} \mathrm{and} \mathrm{then} \mathrm{killed} \mathrm{on} \mathrm{day} \mathrm{73.} \mathrm{D,} \mathrm{Lewis} \mathrm{rats} \mathrm{were} \mathrm{injected}$ on days $0,21,42$, and 98 with $15,22,15$, and 24 pmol chicken brain AChR ( $50 \%$ of which had been denatured in SDS) in CFA, on day 137 with 25 pmol rat brain AChR (purified on mAb 270; Whiting and Lindstrom, 1987a) in CFA, and on day 141 with 32 pmol of AChR in PBS, and killed on day 144.

${ }^{b}$ Determined by Ouchterlony double diffusion using class- and subclass-specific antisera. mAb 268 reacted with both IgGl and IgG2a subclass-specific antisera.

'Titer, ${ }^{125} \mathrm{l}-\alpha$ Bgt binding sites per liter $\mathrm{mAb}(\mu \mathrm{M})$.

${ }^{d}$ Titer, ${ }^{3} \mathrm{H}$-nicotine binding sites bound per liter $\mathrm{mAb}(\mu \mathrm{M})$. Binding of $\mathrm{mAbs}$ to native $\mathrm{AChR}$ in detergent extracts of brain was quantitated by a previously described assay (Whiting and Lindstrom, 1986b; see Materials and Methods). mAbs 267, 268, and 287 exhibited no detectable binding to native AChR, binding only to AChR that had undergone denaturation due to exposure to low $\mathrm{pH}$ (immunoaffinity-purified AChR undergoes some denaturation, as it is eluted from the affinity column by a pH 3.0 buffer; Whiting and Lindstrom, 1986a) or SDS-denatured AChR (Fig. 2). None of the mAbs inhibited the binding of ${ }^{3} \mathrm{H}$-nicotine to $\mathrm{AChR}$ detergent solubilized from chicken brain.

"Subunit specificity was determined by western blot analysis (Fig. 2).

' $\mathrm{mAb} 35$ was prepared from rats immunized with AChR from Electrophorus clectricus electric organ (Tzartos et al., 1981). mAb 210 was prepared from rats immunized with AChR from fetal bovine muscle and the BC3H1 muscle-like mouse cell line (Tzartos et al., 1987).

" mAb 35 has high affinity for the main immunogenic region on $\alpha$ subunits, a conformation-dependent epitope. As discussed in the text, mAb 35 binds weakly to denatured $\alpha$ subunits of AChR from Electrophorus, but not to denatured $\alpha$ subunits from other species. It competes for binding to native AChRs from muscle and brain with mAb 210, which is specific for the $\alpha$ subunit of these AChRs (Whiting and Lindstrom, 1986a; Tzartos et al., 1987).

Whiting and Lindstrom, 1986a), and an additional subunit, $M_{r}$ 75,000 , which we have designated $\beta^{\prime}$ (Fig. 1). The different subunit patterns observed between AChRs purified on mAb 35 and $\mathrm{mAb} 270$ did not represent differences in the sources of chicken brains or differing degrees of proteolysis during separate purifications, because AChRs purified upon mAb 35 and $\mathrm{mAb}$ 270 from a single chicken brain detergent extract that had been divided into 2 gave the same subunit patterns. Additionally, these patterns did not result from different allelic forms of AChR expressed in individual chickens in the batch of brains used for purification because immunohistochemical labeling of thin sections of an individual chicken brain with $\mathrm{mAb} 35$ and $\mathrm{mAb}$ 270 demonstrates that mAb 270 labels all of the areas labeled by mAb 35, plus additional areas (Swanson et al., 1987). Further data on the identity of the $\beta^{\prime}$ subunit came from probing with the mAbs the western blots of AChR purified using mAb 270Sepharose (Fig. 2). mAbs 284, 285, 286, and 289 cxhibited binding to the $75,000 M_{\mathrm{r}} \beta^{\prime}$ subunit. All of these mAbs also bound to intact AChRs with high affinity for nicotine, demonstrating that $\beta^{\prime}$ was part of an $\mathrm{AChR}$ macromolecule. $\mathrm{mAb}$ 286 binds to both the $75,000 M_{\mathrm{r}} \beta^{\prime}$ subunit of chicken AChR and the $79,000 M_{\mathrm{r}} \beta$ subunit of AChR from rat brain (Fig. 2 and Whiting and Lindstrom, 1987a), showing that these are homologous subunits. mAb 267 binds strongly to both $\alpha$ and $\beta$ subunits. mAb 286 binds to $\beta^{\prime}$ subunits and cross-reacts weakly with $\alpha$ subunits. Binding of mAbs to more than one subunit has been previously observed with $\mathrm{mAbs}$ to AChR from Torpedo electric organ (Gullick and Lindstrom, 1983), and probably reflects the sequence homology between subunits (Noda et al., 1983b).

To determine which subunits were associated together in the AChR macromolecule, AChR was affinity-purified on mAb 270 Sepharose, radioiodinated, and tested for binding to each of the mAbs. The AChR bound by each $\mathrm{mAb}$ was analyzed by SDSPAGE and autoradiography (Fig. 3). The results clearly suggest that 2 subtypes exist: a subtype composed of $\alpha$ and $\beta$ subunits, bound by mAb 35, and a subtype composed of $\alpha$ and $\beta^{\prime}$ subunits, bound by mAb 284 (and also by mAbs 285 and 289; data not shown). Both subtypes are bound by mAb 270, reflecting the specificity of $\mathrm{mAb} 270$ for the $\alpha$ subunit, because, as is discussed below, the $\alpha$ subunits of the $2 \mathrm{AChR}$ subtypes are very similar, or identical.

The data presented in Figure 3 suggest that $\mathrm{mAb} 35$ binds almost exclusively to the AChR subtype with $\beta$ subunits. How- 


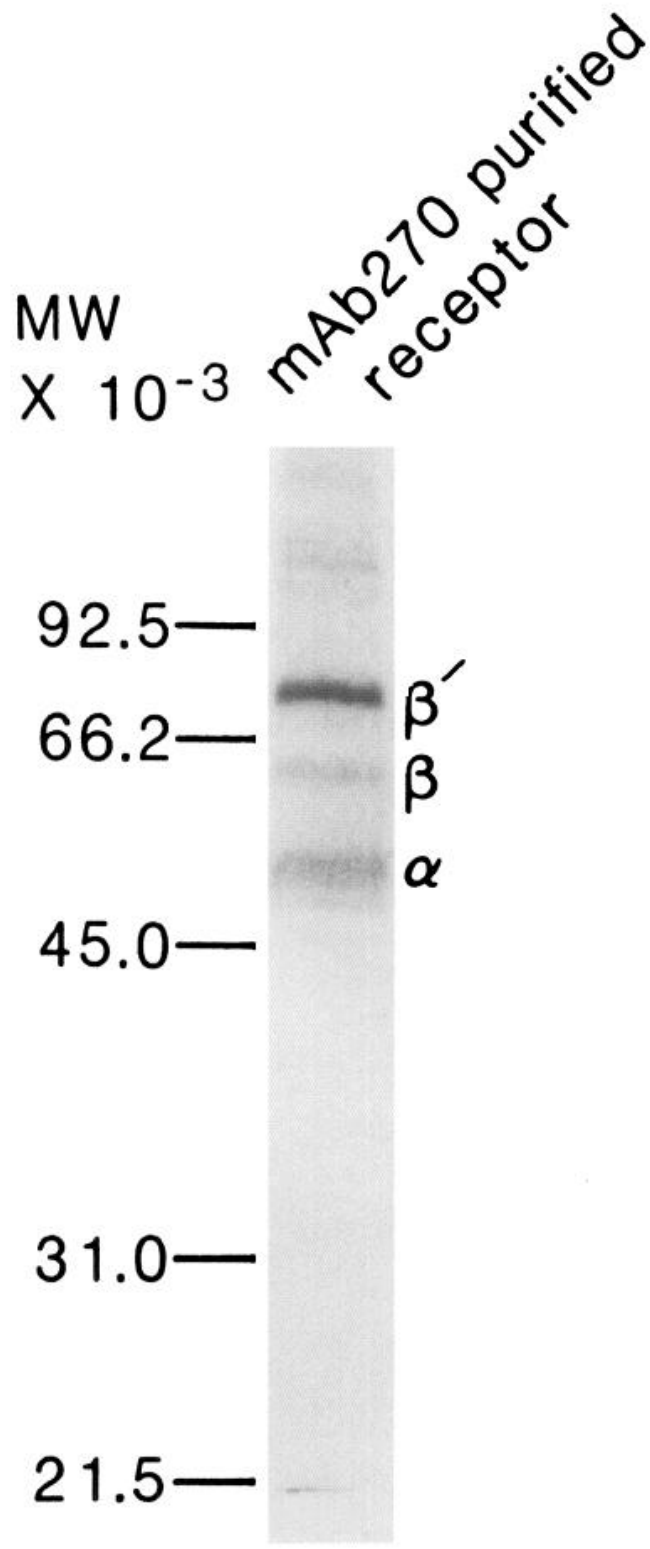

Figure 1. Subunits of AChRs purified from chicken brains using $\mathrm{mAb}$ 270. Nicotinic AChRs from chicken brain were purified through 2 rounds of immunoaffinity chromatography on mAb 270 coupled to Sepharose CL4B. Purified protein was analyzed by SDS-PAGE on a $10 \%$ gel, followed by silver-staining. Apparent subunit molecular weights were determined using low-molecular-weight standards (BioRad) resolved on the same gel.

ever, this mAb must exhibit some binding to the AChR subtype with $\beta^{\prime}$ subunits because, as we have shown above, $4 \mathrm{mAbs}$ directed to the $\beta^{\prime}$ subunit were obtained from rats immunized with AChR affinity-purified from chicken brains using mAb 35Sepharose. To investigate the reactivity of $\mathrm{mAb} 35$ with the AChR subtype characterized by $\beta^{\prime}$ subunits, the binding of ${ }^{125} \mathrm{I}-$ mAb 35, and also ${ }^{125} \mathrm{I}-\mathrm{mAb} 270$, to AChR immobilized upon mAb 285-Sepharose was determined (Fig. 4). ${ }^{125} \mathrm{I}-\mathrm{mAb} 270$ binds strongly to AChRs immobilized on mAb 285-Sepharose. ${ }^{125} \mathrm{I}-\mathrm{mAb} 35$ binds only weakly to this $\mathrm{AChR}$ subtype. The $K_{\mathrm{d}}$ for binding of mAb 35 to the AChR subtype characterized by $\beta^{\prime}$ subunits (as determined by extrapolation of the curve to the half-maximal binding) was approximately $35 \mathrm{nM}$, considerably greater than the $K_{\mathrm{d}}$ of $0.5 \mathrm{~nm}$ for binding to the AChR subtype characterized by $\beta$ subunits (determined from the binding of ${ }^{125} \mathrm{I}-\mathrm{mAb} 35$ to solubilized AChR by DEAE assay; data shown in Whiting and Lindstrom, 1986a). The $\beta^{\prime}$ subunit must be highly immunogenic, because this polypeptide was probably only a minor component of the immunogen used for preparation of the mAbs (it was not visualized in silver-stained preparations of $\mathrm{AChR}$ purified on $\mathrm{mAb} 35$ ), yet 4 of the $8 \mathrm{mAbs}$ subsequently derived were directed against it.

\section{Comparison of structural and ligand-binding properties of the AChR subtypes}

There is strong indirect evidence that mAb 35 binds to the $\alpha$ subunit of AChRs from chicken brain. mAb 35 was prepared to AChRs from electric organ (see Table 1). It is directed at the main immunogenic region (a domain on the extracellular surface of $\alpha$ subunits of AChRs from electric organ and muscle; Tzartos et al., 1981). mAb 35 binds weakly to denatured $\alpha$ subunits of AChR from Electrophorous and competes for binding to native AChRs with mAb 210. mAb 210 was prepared to AChR from muscle. It binds to native AChRs and denatured $\alpha$ subunits of AChRs from electric organ (Ratnam et al., 1986), skeletal muscle (Tzartos et al., 1987) and chicken brain (Whiting and Lindstrom, 1986a). Like mAb 35, mAb 210 also binds only to native chicken brain AChRs of the $\alpha \beta$ subtype; yet it binds to the denatured $\alpha$ subunits of both subtypes on western blots (data not shown).

The differential binding of the $\alpha$ subunit-specific mAbs 35 and 210 to the $A C h R$ subtypes might reflect either differences in the amino acid sequence of the $\alpha$ subunits of the $2 \mathrm{AChR}$ subtypes or differences in the conformation or accessibility of $\alpha$ determinants in association with $\beta$ subunit types that differ so much in size. To investigate these possibilities, peptide mapping was performed on the isolated $\alpha$ subunits of each AChR subtype. AChR was immunoaffinity-purified on mAb $270 \mathrm{Se}$ pharose, radioiodinated, and then the 2 subtypes were obtained by repurification on $\mathrm{mAb} 35-$ Sepharose or $\mathrm{mAb}$ 285-Sepharose. Subunits from each preparation were isolated by preparative electrophoresis. The $\alpha$ subunits were then subjected to proteolytic digestion with Staphylococcus V8 protease (Fig. 5). The peptide maps obtained were essentially indistinguishable, although minor differences may exist between peptides from $M_{\mathrm{r}}$ 14,000 to 21,000 . We have previously reported that peptide mapping can be used to demonstrate differences between the $\alpha$ subunits of AChRs from Torpedo electric organ and AChR from chicken brain (Whiting and Lindstrom, 1986a). Thus, the peptide maps in Figure 5 suggest that the 2 subunits are very similar, perhaps identical. Additionally, when western blots of AChR subtypes (purified on mAb 35- and mAb 285-Sepharose) were probed with mAbs directed at the $\alpha$ subunit $(210,267,268$, 270,287 ), binding to $\alpha$ subunits of both AChR subtypes was observed (data not shown). Thus, differential binding of mAb 35 and mAb 210 to native AChR subtypes is unlikely to be due to substantial sequence differences between the $\alpha$ subunits of the AChRs of each subtype. The ability of mAb 35 to bind depends strongly on the conformation of the $\mathrm{AChR}$, and it does not bind to denatured $\alpha$ subunits of neuronal AChRs (data not shown). The association of $\alpha$ subunits with $\beta^{\prime}$ subunits may cause a conformation that does not bind mAbs 35 or 210 , or the larger $\beta^{\prime}$ subunit may simply obscure the binding site for these mAbs on the $\alpha$ subunit, whereas the smaller $\beta$ subunit does not. 


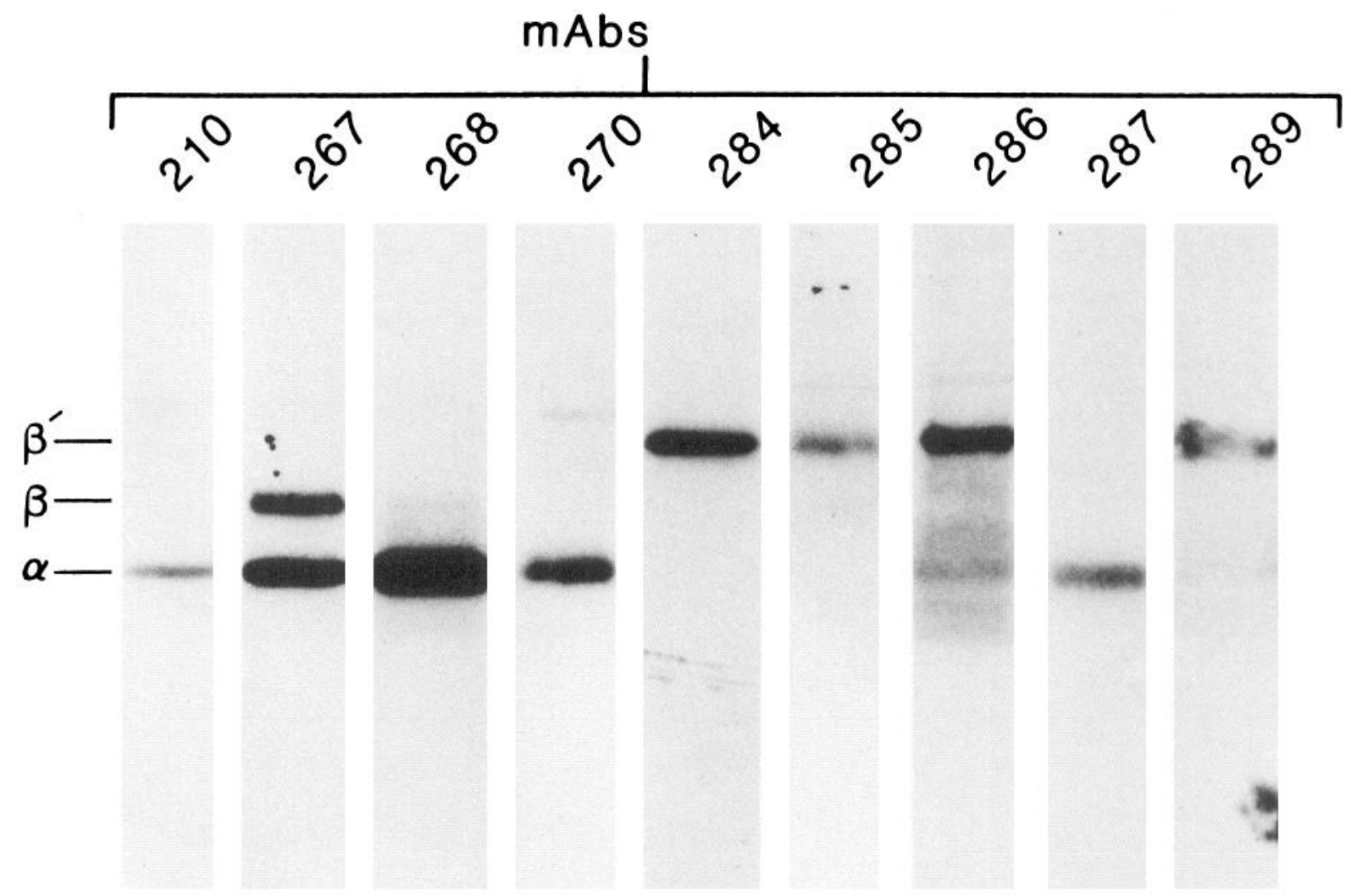

Figure 2. Subunit specificity of mAbs made to AChRs from chicken brains. AChR was affinity-purified from chicken brains on mAb 270 Sepharose. Subunits were resolved by SDS-PAGE on a $10 \%$ gel, and then transferred to diazophenylthioether paper. Each lane, containing approximately 2 pmol of $\mathrm{AChR}$, was probed with 1:50 dilution of each mAb. Bound mAbs were visualized by means of $0.5 \mathrm{nM}{ }^{125} \mathrm{I}-\mathrm{goat}$ anti-rat IgG and autoradiography at $-70^{\circ} \mathrm{C}$ using preflashed Kodak XAR film and a Cronex intensifying screen. Molecular-weight markers (BioRad) were resolved on the same polyacrylamide gel, the lane excised and stained for protein.

The affinity of the $2 \mathrm{AChR}$ subtypes for $\mathrm{DL}^{-3} \mathrm{H}$-nicotine was investigated by immobilizing AChRs on mAb 35-Sepharose or $\mathrm{mAb} 285$-Sepharose and then determining binding curves for the radioligand, as previously described (Whiting and Lindstrom, 1986b). Scatchard analysis of the binding curves (data not shown) gave superimposable plots for the $2 \mathrm{AChR}$ subtypes, both with an apparent $K_{\mathrm{d}}$ of $6.2 \mathrm{nM}$ (true $K_{\mathrm{d}}$ of $3.1 \mathrm{nM}$; see below), a value identical to that reported previously for $\mathrm{AChR}$ immobilized on mAb 35-Sepharose (Whiting and Lindstrom, 1986b). The pharmacology of the 2 AChR subtypes, determined by inhibition of $\mathrm{DL}^{-3} \mathrm{H}$-nicotine binding by various cholinergic ligands to $\mathrm{AChR}$, immobilized upon mAb 35 or 285 coupled to Sepharose (and subsequent determination of the $K_{\mathrm{i}}$ values), is also not significantly different (Table 2 ). The correlation coefficient for the collective $K_{\mathrm{i}}$ values in Table 2 is $R=0.99$. Both subtypes exhibit very similar high-affinity stereospecific binding for L-nicotine. The apparent $K_{\mathrm{d}}$ for $\mathrm{DL}^{-3} \mathrm{H}$-nicotine binding of $6.2 \mathrm{~nm}$ is actually $3.1 \mathrm{nM}$, since the ratio of isomers in the racemic radioligand preparation is $1: 1$ (NEN; personal communication), and therefore the concentration of $\mathrm{L}-{ }^{3} \mathrm{H}$-nicotine in each assay tube was actually $50 \%$ of that added. The true $K_{\mathrm{d}}$ of $3.1 \mathrm{nM}$ is, thus, in reasonable agreement with the $K_{\mathrm{i}}$ values of 1.1 and 1.6 $\mathrm{nm}$ for L-nicotine binding to the AChR subtypes. Others have similarly found that L-nicotine binds with much higher affinity than does D-nicotine to sites in avian and rodent brain membranes $\left(K_{\mathrm{i}}\right.$ values for L-nicotine range from 2 to $6 \mathrm{nM}$, and for D-nicotine range from 120 to $146 \mathrm{nM}$; Schwartz et al., 1982;
Schneider et al., 1985; Yamada et al., 1985; Lippiello and Fernandes, 1986).

The data from Table 2 (showing that the ligand-binding properties of the two AChR subtypes are identical) might be considered, together with the data of Figure 5 (showing that the $\alpha$ subunits of both AChR subtypes are similar or identical) and of Figure 3 (showing that the $\beta$ subunits of each subtype are different), as suggesting that the ligand-binding sites were on the $\alpha$ subunits. The antigenic homologies between the $\alpha$ subunits of AChRs from electric organs, which are the ligand-binding subunits of their AChR (Kao and Karlin, 1986), and the $\alpha$ subunits of AChRs from brain (Fig. 2; Whiting and Lindstrom, 1986a, 1987a) would also suggest that the the ligand-binding sites should be found on $\alpha$ subunits of AChRs from brain. However, this is not the case.

Previously, we demonstrated that, after reduction with dithiothreitol, AChRs from chicken brain (Whiting and Lindstrom, 1986b, 1987b) and ganglia (Stollberg et al., 1986) can be affinity-labeled with the reagents MBTA and BAC. This blocks nicotine binding of isolated brain $\mathrm{AChRs}$ and blocks the function of AChRs in cultured ganglionic neurons. Karlin and coworkers have shown that, in Torpedo AChRs, cysteines $\alpha 192$ and $\alpha 193$ are linked by a disulfide bond (Kao and Karlin, 1986), and that, after reduction of this bond, these cysteines are affinitylabeled by MBTA (Kao et al., 1984). These results suggest that AChRs on chicken neurons that are labeled by MBTA have a cysteine pair homologous to $\alpha 192-193$. In fact, when we used 
Figure 3. Resolution of $\mathrm{AChR}$ subtypes by immunoprecipitation with mAbs. Both AChR subtypes were simultaneously affinity-purified from chicken brains using $\mathrm{mAb} 270-\mathrm{Se}-$ pharose. The purified AChR preparation containing both subtypes was radioiodinated. Aliquots of $3.5 \times 10^{6} \mathrm{cpm}$ of the AChRs were incubated with $\mathrm{mAb}$ 270 to bind both AChR subtypes, with mAb 35 to bind the $\alpha \beta$ subtype, and with mAb 284 to bind the $\alpha \beta^{\prime}$ subtype, or with normal rat serum $(2 \mu \mathrm{l})$ as a control. They were then gently shaken for $15 \mathrm{hr}$ at $4^{\circ} \mathrm{C}$ in $100 \mu \mathrm{l}$ of PBS, $0.5 \%$ Triton X-100 containing 5\% (wt/vol) nonfat milk powder with $20 \mu$ l goat antirat IgG Sepharose to precipitate the immunecomplexes. Theimmuneprecipitates were washed 4 times with $1 \mathrm{ml}$ of PBS, $0.5 \%$ Triton $\mathrm{X}-100$ by pelleting in a microfuge and resuspending. Bound protein was then eluted with $60 \mu \mathrm{l}$ of $125 \mathrm{~mm}$ Tris- $\mathrm{HCl}, \mathrm{pH} 6.8$, containing $2.3 \%(\mathrm{wt} / \mathrm{vol}) \mathrm{SDS}, 10 \%(\mathrm{vol} / \mathrm{vol})$ glycerol, and $0.005 \%$ (wt $/ \mathrm{vol}$ ) bromophenol blue. Samples were made $5 \%(\mathrm{vol} / \mathrm{vol})$ in $\beta$-mercaptoethanol. The subunits in the AChR subtypes bound by each $\mathrm{mAb}$ were resolved by SDS-PAGE on $10 \%$ gels, the gel dried and autoradiographed. In order to estimate the subunit ratios in each AChR subtype, the band intensities were quantitated on a scanning densitometer (Hoeffer Scientific Instruments) and the relative intensity of each subunit was expressed as a ratio, shown beneath each lane.

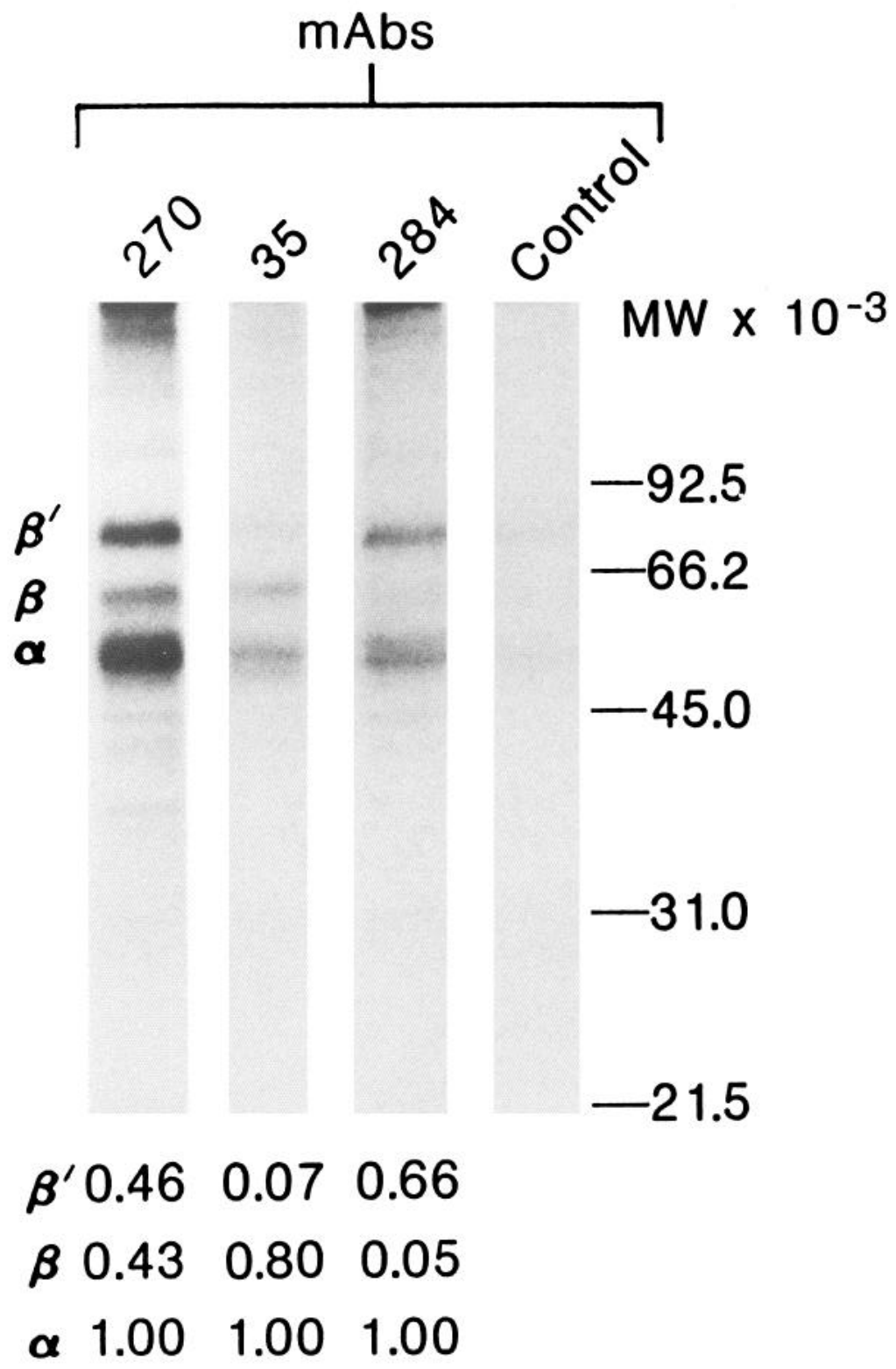

depleted greater than $90 \%$ of the $\mathrm{DL}^{-3} \mathrm{H}$-nicotine binding sites (data not shown), as has been previously demonstrated (Whiting and Lindstrom, 1986b). mAbs 35 and 285 could individually remove approximately $50 \%$ of the ${ }^{3} \mathrm{H}$-nicotine binding sites, but when incubated together could deplete more than $90 \%$ of the sites. These data confirm the existence of the 2 AChR subtypes, and indicate that they are present in approximately equal amounts in adult chicken brain. The proportion of these AChR subtypes in embryonic chicken brain was also investigated (Fig. 7). As in adult chicken brain, $\mathrm{mAb} 270$ depleted greater than $89 \%$ of

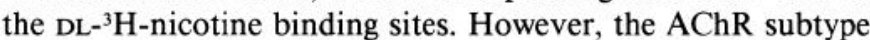
with $\beta$ subunits (bound by mAb 35) made up a smaller proportion of the total AChRs than it did in adult brain, while the AChR subtype with $\beta^{\prime}$ subunits (bound by $\mathrm{mAb} 285$ ) represented a larger proportion.

\section{Subunit stoichiometry}

In order to determine whether more than one copy of a subunit was present in an $\mathrm{AChR}$ macromolecule, we tested to see whether an AChR immobilized via a subunit-specific $\mathrm{mAb}$ was able 


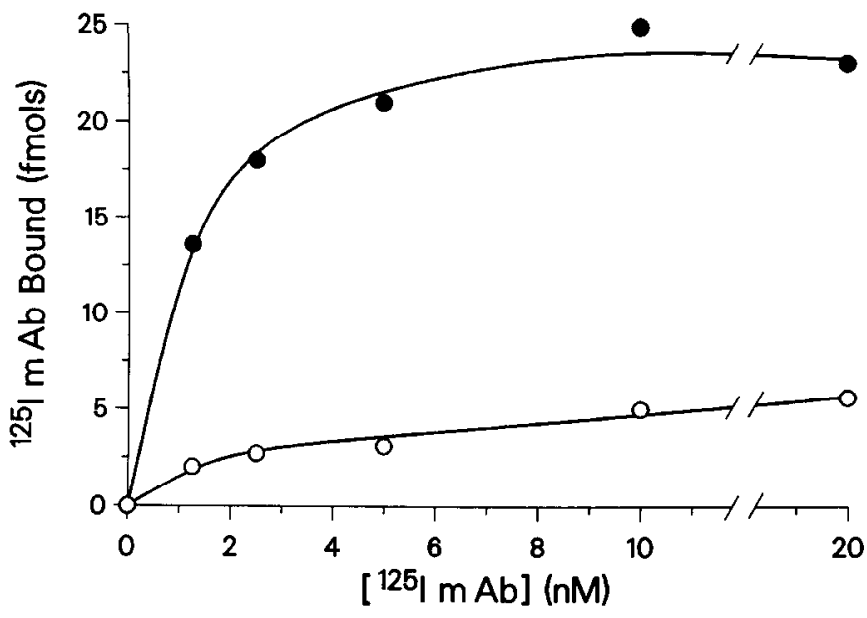

Figure 4. Relative affinities of mAb 270 and mAb 35 for AChRs of the $\alpha \beta^{\prime}$ subtype. Measurement was made of the binding of ${ }^{125}$ I-labeled mAb $35(O)$ or $270(0)$ to AChRs of the $\alpha \beta^{\prime}$ subtype, immobilized on $\mathrm{mAb} 285$-Sepharose. Chicken brain detergent extract $(200 \mu \mathrm{l})$ was gently shaken for $15 \mathrm{hr}$ at $4^{\circ} \mathrm{C}$, with $20 \mu \mathrm{l}$ of mAb 285 coupled to Sepharose CL4B (13.25 mg protein $/ \mathrm{ml}$ Sepharose), and various concentrations of ${ }^{125} \mathrm{I}-\mathrm{mAb} 35$ and ${ }^{125} \mathrm{I}-\mathrm{mAb} 270$ (radiolabeled by a modified chloramine$\mathrm{T}$ method to specific activities of $1-3 \times 10^{18} \mathrm{cpm} / \mathrm{mol}$; Lindstrom et al., 1981). The aliquots were washed 3 times with $1 \mathrm{ml}$ of PBS containing $0.5 \%$ Triton $\mathrm{X}-100$ by pelleting in a microfuge and resuspending, and bound radioactivity was determined by gamma counting. Nonspecific binding was determined by parallel incubations in the presence of excess nonradioactive mAb $35(6 \mu \mathrm{M})$ and $\mathrm{mAb} 270(0.2 \mu \mathrm{M})$, and was subtracted. Each point is the mean of triplicate incubations.

to bind additional molecules of that same mAb. Figure 8 clearly indicates that for both the $\alpha$-specific mAbs 35 and 270 and the $\beta^{\prime}$-specific mAb 285, this was the case. Thus, the subunit stoichiometry is $\alpha_{n \geq 2} \beta_{n \geq 2}$. The number of mAb 35 binding sites immobilized upon mAb 35-Sepharose, as determined from the depletion of ${ }^{125} \mathrm{I}-\mathrm{mAb} 35$ binding sites from brain detergent extracts, as measured by the DEAE assay previously described (Whiting and Lindstrom, 1986a), was $24.6 \mathrm{fmol}$ in the experiment shown in Figure $8 B$. If there were $2 \alpha$ subunits per $\mathrm{AChR}$, and each $A C h R$ were immobilized through one $\alpha$ subunit, then $12.3 \mathrm{fmol}$ of binding sites should still be available for ${ }^{125} \mathrm{I}-\mathrm{mAb}$ 35 binding. In fact, 6.8 fmol of ${ }^{125} \mathrm{I}-\mathrm{mAb} 35$ were bound. Although this was less than the number of theoretical binding sites, it clearly indicates that there is more than one $\alpha$ per AChR. The reduced number of binding sites observed could be due to binding of both $\alpha$ subunits on some AChRs by immobilized mAb, to the short incubation time with the ${ }^{125} \mathrm{I}-\mathrm{mAb}$, to steric hindrance, or to elution of immobilized AChR by the free ${ }^{125 I-}$ $\mathrm{mAb}$.

The chicken brain AChR macromolecule sediments on sucrose gradients at a rate intermediate between Torpedo AChR monomers $\left(M_{r} 268,000\right.$ protein, $\sim 302,000$ plus sugar $)$ and dimers $(M, 536,000$ protein) (Lindstrom et al., 1983; Whiting and Lindstrom, 1986a). The calculated molecular weights of $\alpha_{n} \beta_{n}$, with $n=2$ or 3, range between 216,000 and 323,000 for chicken brain AChRs, which is of this order, but the accuracy of these measurements does not permit a precise determination.

The ratio of subunits obtained from densitometric scanning of the autoradiograms in Figure 3 is most consistent with $\alpha_{2} \beta_{3}$ or $\alpha_{3} \beta_{2}$ stoichiometries, but this assumes that ${ }^{125} \mathrm{I}$ is incorporated equivalently in both subunits per unit weight. Thus, these data also fail to absolutely define the stoichiometry.
Table 2. Inhibition of $\mathrm{DL}^{-3} \mathrm{H}$-nicotine binding to chicken brain $\mathrm{AChR}$ subtypes by cholinergic ligands

\begin{tabular}{|c|c|c|}
\hline \multirow[b]{2}{*}{ Ligand } & \multicolumn{2}{|l|}{$K_{\mathrm{i}}(\mathrm{M})$} \\
\hline & $\begin{array}{l}\text { mAb 35-Sepha- } \\
\text { rose-immobilized } \\
\text { AChR } \\
\text { ( } \alpha \beta \text { AChR subtype) }\end{array}$ & $\begin{array}{l}\text { mAb } 285-S e- \\
\text { pharose- } \\
\text { immobi- } \\
\text { lized AChR } \\
\left(\alpha \beta^{\prime} \mathrm{AChR}\right. \\
\text { subtype })\end{array}$ \\
\hline L-Nicotine & $1.1 \times 10^{-9}$ & $1.6 \times 10^{-9}$ \\
\hline Cytisine & $1.1 \times 10^{-9}$ & $1.4 \times 10^{-9}$ \\
\hline Carbachol & $8.4 \times 10^{-8}$ & $1.4 \times 10^{-7}$ \\
\hline Decamethonium & $8.7 \times 10^{-6}$ & $3.0 \times 10^{-6}$ \\
\hline Curare & $1.1 \times 10^{-5}$ & $3.7 \times 10^{-6}$ \\
\hline Hexamethonium & $>10^{-3}$ & $>10^{-3}$ \\
\hline Mecamylamine & $>10^{-3}$ & $>10^{-3}$ \\
\hline$\alpha \mathrm{Bgt}$ & $>10^{-6}$ & $>10^{-6}$ \\
\hline Atropine & $>10^{-3}$ & $>10^{-7}$ \\
\hline
\end{tabular}

Inhibition of $\mathrm{DL}-{ }^{3} \mathrm{H}-$ nicotine binding to AChRs immobilized upon antibodySepharose was determined as previously described (Whiting and I indstrom, 1986b) The $K_{\mathrm{i}}$ was calculated from an experimentally determined $\mathrm{IC}_{50}$ value using the equation, $K_{\mathrm{i}}=\mathrm{IC}_{50} / 1+\left({ }^{3} \mathrm{H}\right.$-nicotine $\left./ K_{\mathrm{d}}\right)$.

${ }^{a}$ These values were taken from Whiting and Lindstrom (1986b), with the exception of the $K_{\mathrm{i}}$ for L-nicotine.

The $\alpha_{2} \beta_{3}$ or $\alpha_{3} \beta_{2}$ subunit arrangements are attractive because they would confer a 5-fold symmetry upon the receptor macromolecule, as is found for the $\alpha_{2} \beta \gamma \delta$ structure of Torpedo receptor monomers (Reynolds and Karlin, 1978; Lindstrom et al., 1979; Raftery et al., 1980; Brisson and Unwin, 1984; Kubalek et al., 1987). The $\alpha_{3} \beta_{2}$ stoichiometry is especially appealing because it preserves the symmetry of $2 \mathrm{ACh}$-binding subunits and 3 structural subunits. However, the data are insufficient for concluding more than that the subunit stoichiometry is $\alpha_{n=2-3} \beta_{n=2-3}$.

\section{Discussion}

This is the first report of the production and characterization of $\mathrm{mAbs}$ to neuronal nicotinic AChRs that do not bind $\alpha \mathrm{Bgt}$. This paper describes the use of these mAbs to identify subtypes of AChRs in chicken brains and also to further compare these neuronal AChRs with AChRs from muscle and electric organ.

It has been very important to show that the proteins we have purified and characterized using $\mathrm{mAbs}$ are not simply proteins present in brain that have a limited, fortuitous homology to nicotinic AChRs from electric organ and muscle, but are, in fact, functional neuronal nicotinic AChRs. Many pieces of evidence now indicate that these proteins are neuronal nicotinic ACh receptors: (1) They have a nicotinic cholinergic pharmacology (Whiting and Lindstrom, 1986b, 1987b); (2) they do not bind $\alpha \mathrm{Bgt}$ (Whiting and Lindstrom, 1986a), a ligand about which there is much evidence demonstrating that it does not bind to functional neuronal AChRs in the chicken and mammalian brain (as discussed more fully below); (3) the ACh binding site of these neuronal AChRs, like those of AChRs from electric organ and muscle (see Popot and Changeux, 1984), has a reducible disulfide bond in close proximity that can be labeled with cholinergic affinity reagents (Whiting and Lindstrom, 1987b); (4) antisera prepared to AChRs purified from chicken brain specifically blocked the ACh-induced depolarization of chick ciliary ganglion cells in culture (Stollberg et al., 1986); (5) mAb 270, and also polyclonal antisera to AChRs from chicken brain, could antigenically modulate the functional AChR on rat $\mathrm{PC} 12$ cells 
Figure 5. Peptide maps of the $\alpha$ subunits of both AChR subtypes. AChR was immunoaffinity-purified from chicken brains through 2 rounds of affinity-chromatography on mAb 270 Sepharose, radioiodinated, and the 2 AChR subtypes isolated using $\mathrm{mAb} 35-$ and $\mathrm{mAb} 285$-Sepharose, according to the method described in the legend to Figure 3 . The AChR polypeptides were resolved by SDS-PAGE on a $10 \%$ gel and the subunits located by autoradiography of the wet gel. The polypeptides were eluted from gel slices, as described previously (Whiting and Lindstrom, 1986a), and their purity checked by re-electrophoresis. Digestion of isolated $\alpha$ subunits with Staphylococcus $\mathrm{V} 8$ protease and resolution of the fragments by $15 \%$ SDS-PAGE has been described previously (Whiting and Lindstrom, 1986a). The peptide maps were detected by autoradiography. Lanes 1-5 show mAb 35-purified AChR $\alpha$ subunits. Lanes 6-10 show mAb 285purified AChR $\alpha$ subunits. Lanes 1 and $10,0.008 \mu \mathrm{g}$ Staphylococcus V8 protease; lanes 2 and $9,0.04 \mu \mathrm{g}$ protease; lanes 3 and $8,0.2 \mu \mathrm{g}$ protease; lanes 4 and $7,1.0 \mu \mathrm{g}$ protease; lanes 5 and 6 , $5.0 \mu \mathrm{g}$ protease.

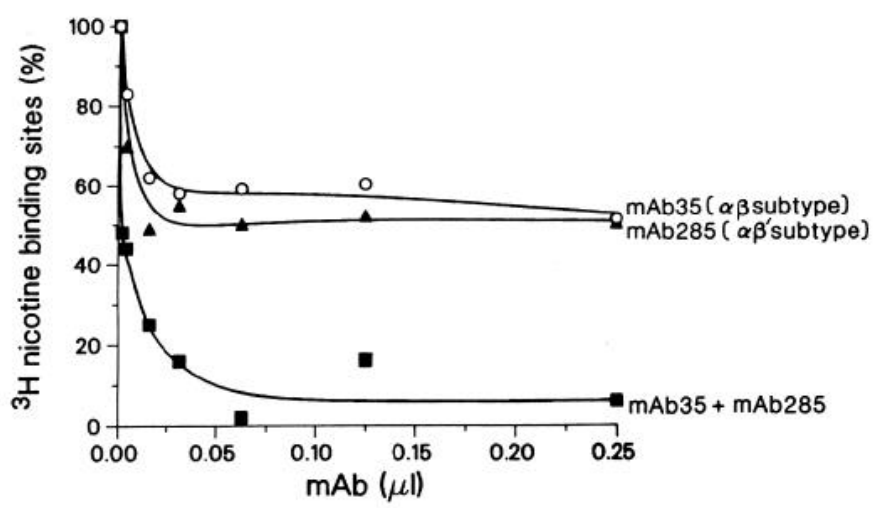

Figure 6. Proportion of AChR subtypes in adult chicken brain. This was determined by depletion of $\mathrm{DL}^{-} \mathrm{H}$-nicotine binding sites from detergent extracts of adult chicken brain by mAb $35(0), \mathrm{mAb} 285(\boldsymbol{\Delta})$, and a combination of mAbs 35 and $285(\square)$. Aliquots $(300 \mu \mathrm{l})$ of chicken brain detergent extract $\left(0.20 \mathrm{nM}{ }^{3} \mathrm{H}\right.$-nicotine binding sites) were gently shaken for $15 \mathrm{hr}$ at $4^{\circ} \mathrm{C}$ with $20 \mu \mathrm{l}$ of goat anti-rat IgG-Sepharose and increasing amounts of mAbs. The Sepharose was pelleted and the supernatant assayed for ${ }^{3} \mathrm{H}$-nicotine binding sites by filtration assay (Schwartz et al., 1982). Briefly, $100 \mu$ l triplicate aliquots were incubated for $1 \mathrm{hr}$ at $4^{\circ} \mathrm{C}$ with $20 \mathrm{nM}{ }^{3} \mathrm{H}$-nicotine and then diluted with $4 \mathrm{ml}$ of

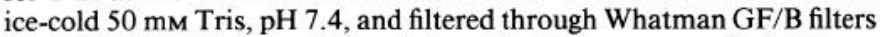
presoaked in $0.3 \%$ polyethyleneimine. The filters were washed 3 times with $4 \mathrm{ml}$ of the same buffer and bound radioactivity determined by scintillation counting. Nonspecific binding was determined by incubation in the presence of $1 \mathrm{~mm}$ nonradioactive nicotine, and has been subtracted. The total $\mathrm{DL}-{ }^{3} \mathrm{H}$-nicotine binding sites (considered $100 \%$ ) were determined by incubation with goat anti-rat IgG-Sepharose alone, and all values were expressed relative to this. $\begin{array}{llllllllll}1 & 2 & 3 & 4 & 5 & 6 & 7 & 8 & 9 & 10\end{array}$

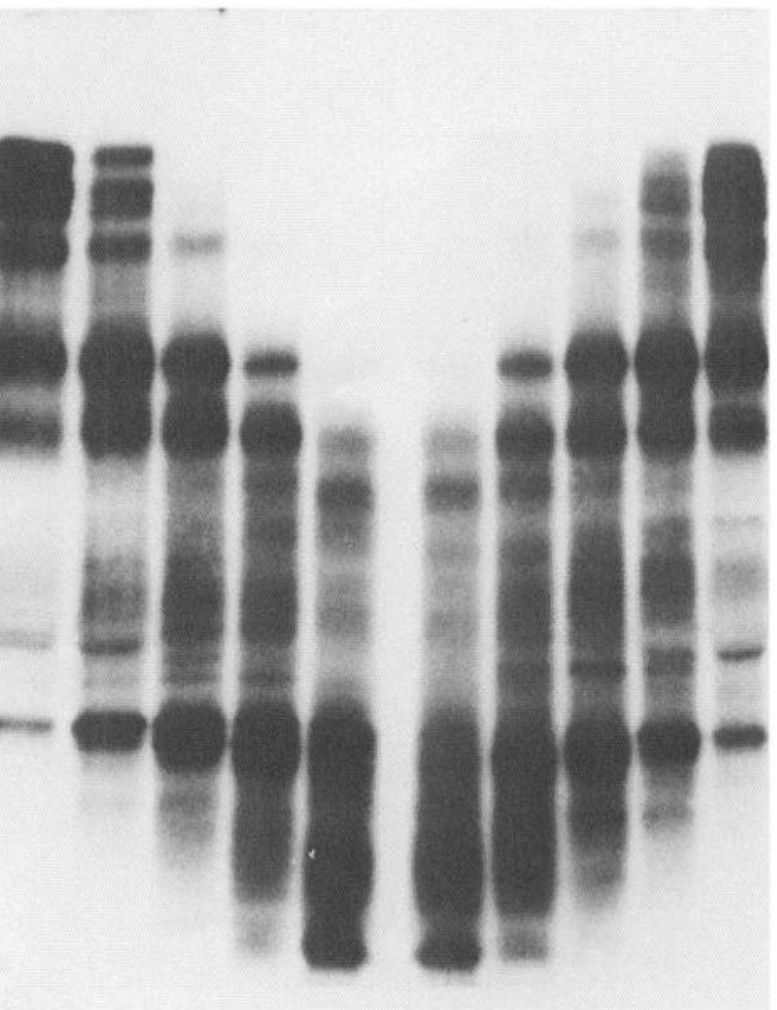

(Whiting et al., 1987b); (6) the N-termini of their subunits show homology to subunits of AChRs from electric organ and skeletal muscle (Whiting et al., 1987c, and unpublished observations).

An alternative and complementary approach to identifying and characterizing neuronal nitocinic AChRs has been taken by Patrick and Heinemann and their coworkers. They have screened cDNA libraries prepared from $\mathrm{PC} 12$ cells and rat brain at low stringency with probes constructed from mouse muscle AChR $\alpha$ subunit cDNA in an attempt to isolate cDNA clones coding for subunits of neuronal nicotinic AChRs. A similar approach to isolating cDNAs from chicken brain has been taken by Ballivet and coworkers (Nef et al., 1986). Patrick and coworkers isolated a putative neuronal $\mathrm{AChR} \alpha$ subunit $\mathrm{cDNA}$ clone from PC12 cells ( $\lambda$ PCA48, now referred to as $\alpha_{3}$ ) with significant sequence homology to muscle $\mathrm{AChR} \alpha$ subunits (Boulter et al., 1986). Treatment of PC12 cells with $\beta$ NGF induced a parallel increase in functional AChRs and binding sites for mAb 270, but neither the number of $\alpha$ Bgt binding sites nor the amount of mRNA that hybridizes with $\lambda$ PCA48 was increased by $\beta$ NGF treatment (Whiting et al., 1987b). These results suggest that synthesis of PC12 AChR may not be regulated at the level of transcription of $\alpha_{3}$, or that $\alpha_{3}$ may not code for an AChR subunit, but may code for a subunit of the $\alpha$ Bgt binding component. More recently, Patrick and coworkers have isolated from rat brain a second cDNA clone, $\alpha_{4}$ (Goldman et al., 1987). We had previously determined the $\mathrm{N}$-terminal amino acid sequence of the $M_{\mathrm{r}} 79,000 \beta^{\prime}$ subunit of AChRs purified from rat brain, and this was identical to residues 27-43 of cDNA clone $\alpha_{4}$, indicating that $\alpha_{4}$ codes for the $\beta^{\prime}$ subunit of the nicotinic AChR from rat brain (Whiting et al., 1987c). Thus, immunochemical, biochemical, and cDNA techniques are complementary, and the bio- 

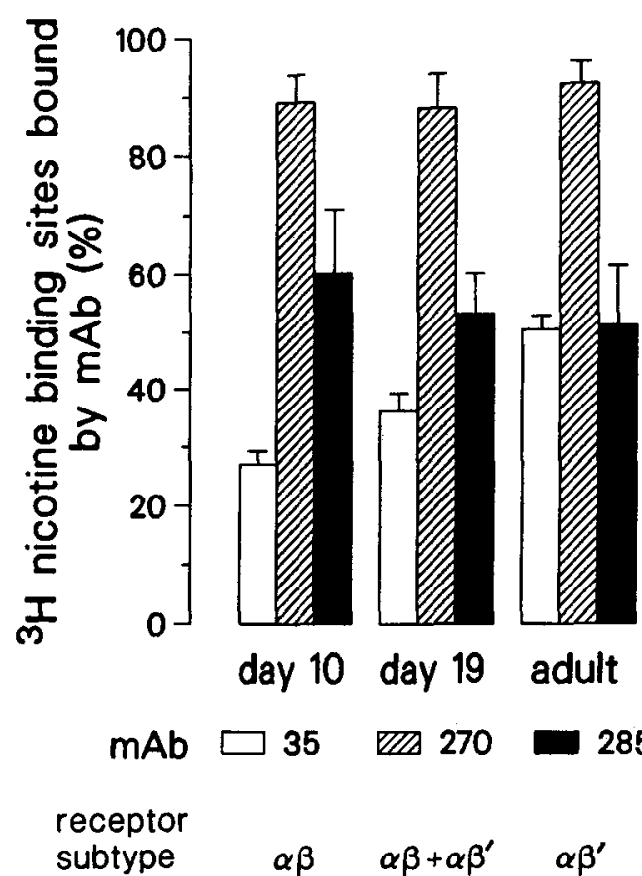

Figure 7. Proportion of AChR subtypes in detergent extracts of brains from day 10 and day 19 chick embryos and adult chickens. Detergent extracts $(350 \mu \mathrm{l})$ of brains from day 10 and day 19 chick embryos were gently shaken for $15 \mathrm{hr}$ at $4^{\circ} \mathrm{C}$ with $20 \mu \mathrm{l}$ of mAb 35-Sepharose $(10 \mathrm{mg} /$ $\mathrm{ml}$ Sepharose), mAb 270-Sepharose (6 mg/ml Sepharose), mAb 285 Sepharose $(13.25 \mathrm{mg} / \mathrm{ml}$ Sepharose) and goat anti-rat IgG Sepharose. The Sepharose was pelleted and $100 \mu \mathrm{l}$ aliquots of supernatant assayed for $\mathrm{DL}-{ }^{3} \mathrm{H}$-nicotine binding, as described in the legend to Figure 6 . Results (mean $\pm \mathrm{SD}$ of triplicate determinations) are expressed, considering as $100 \%$ the $\mathrm{DL}-{ }^{3} \mathrm{H}$-nicotine binding sites in extracts incubated with goat anti-rat IgG-Sepharose. Data for adult chicken brain were taken from Figure 6.

chemical techniques can determine the identity and subunit composition of the products of putative AChR subunit cDNA clones.

Many of the mAbs prepared to AChRs from chicken brain (and also polyclonal antisera to these AChRs) exhibited crossreactivity with high-affinity nicotine binding sites in the brains of several other animal species, demonstrating that homologous neuronal nicotinic AChRs are found in other vertebrate organisms. The binding to AChRs from Torpedo brain was also investigated, using mAb 35 and $\mathrm{mAbs}$ to $A C h R s$ from chicken brain and rat brain ( $P$. Whiting and $J$. Lindstrom, unpublished observations), but we were unable to demonstrate the presence of any high-affinity ${ }^{3} \mathrm{H}$-nicotine binding sites in detergent extracts, which suggests that AChRs with this pharmacological property have not evolved in elasmobranchs. Neuronal nicotinic AChRs of the ganglionic type, with similar antigenic structure (Stollberg et al., 1986; Whiting et al., 1987b) but low affinity for ACh and nicotine (Halvorsen and Berg, 1986; Kemp and Morley, 1986), would not have been detected. Evolution of neuronal AChRs of this type may have preceded the relatively recent evolution of $\mathrm{AChRs}$ with very high affinity for nicotine. The Torpedo brain extract did have ${ }^{125} \mathrm{I}-\alpha \mathrm{Bgt}$ binding sites ( 2 $\mathrm{pmol} / \mathrm{gm}$ tissue) that were not bound by antibodies to AChRs from electric organ, indicating that these sites may be analogous to the $\alpha \mathrm{Bgt}$ binding sites of avian and mammalian brain that are not bound by mAb 35 or mAbs to AChRs from chicken brain.

None of the mAbs to AChRs from chicken brain exhibited

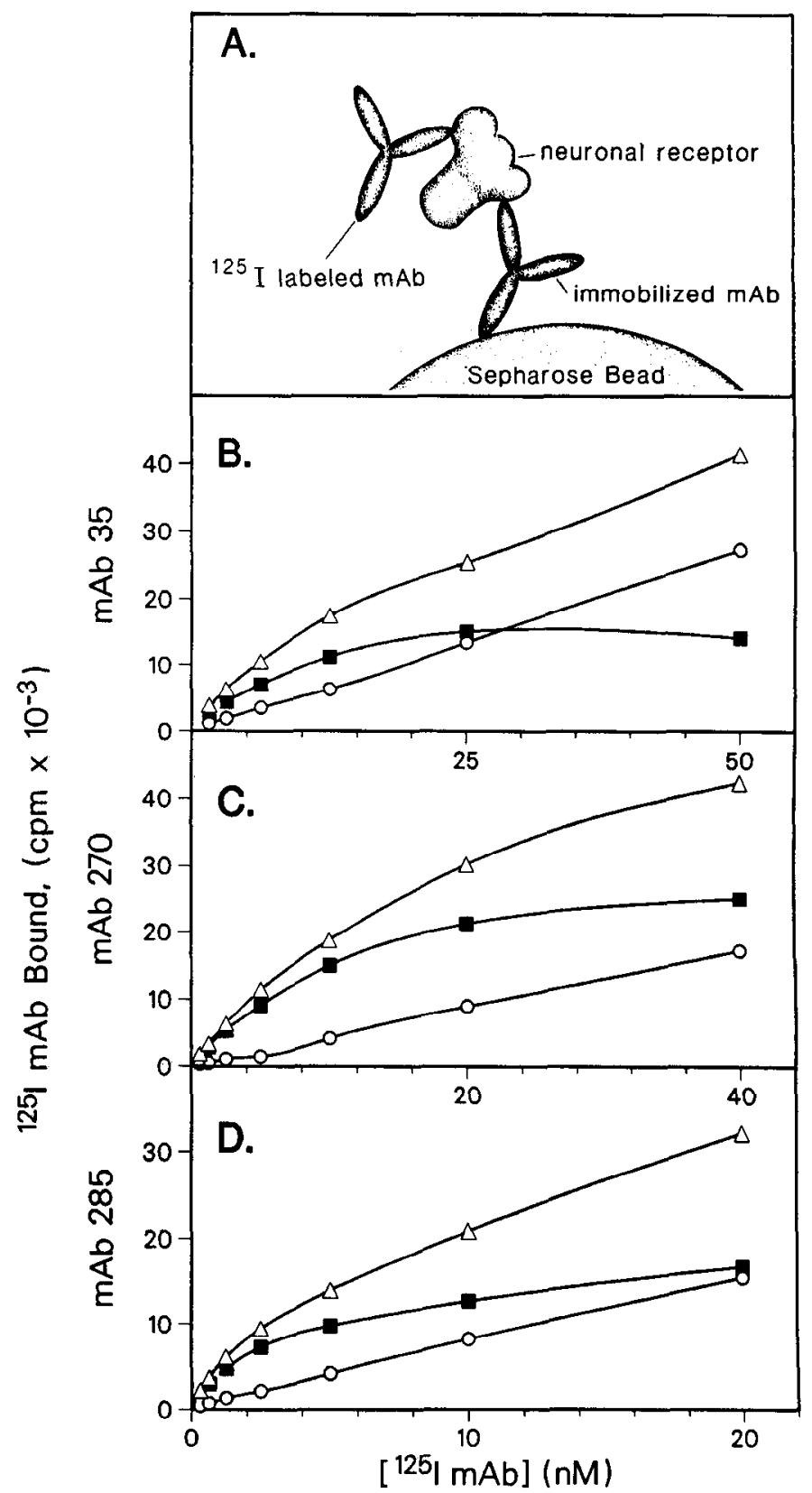

Figure 8. More than one copy of $\alpha$ and $\beta^{\prime}$ subunits is present in each neuronal AChR macromolecules. $A$, Diagrammatic representation of binding assay. $B$, Binding of ${ }^{125} \mathrm{I}-\mathrm{mAb} 35$ to $A C h R$ immobilized upon $\mathrm{mAb} 35$-Sepharose. $C$, Binding of ${ }^{125} \mathrm{I}-\mathrm{mAb} 270$ to AChR immobilized upon mAb 270-Sepharose. $D$, Binding of ${ }^{125} \mathrm{I}-\mathrm{mAb} 285$ to AChR immobilized upon mAb 285-Sepharose. Chicken brain detergent extract $(200 \mu \mathrm{l})$ was gently shaken for $15 \mathrm{hr}$ at $4^{\circ} \mathrm{C}$ with $15 \mu \mathrm{l}$ of a $1: 1$ slurry of $m A b$ 35-Sepharose, mAb 270-Sepharose, and mAb 285-Sepharose. The aliquots were washed with $1 \mathrm{ml}$ PBS, $0.5 \%$ Triton X-100, and then incubated for $1 \mathrm{hr}$ at $22^{\circ} \mathrm{C}$ in $100 \mu \mathrm{PBS}, 0.5 \%$ Triton X-100 containing increasing concentrations of ${ }^{125} \mathrm{I}$-labeled $\mathrm{mAb} 35\left(2.2 \times 10^{18} \mathrm{cpm} / \mathrm{mol}\right)$, $\mathrm{mAb} 270\left(0.94 \times 10^{18} \mathrm{cpm} / \mathrm{mol}\right)$, and $\mathrm{mAb} 285\left(3.9 \times 10^{18} \mathrm{cpm} / \mathrm{mol}\right)$ radiolabeled by a modified chloramine-T method (Lindstrom et al. 1981). Parallel incubations were carried out in which aliquots were preincubated for $30 \mathrm{~min}$ with excess nonradioactive $\mathrm{mAb}$ (final con-

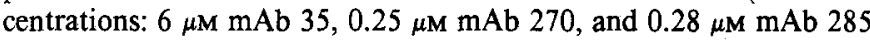
before addition of ${ }^{125}$-labeled $\mathrm{mAb}$ ). The aliquots were washed 4 times with $1 \mathrm{ml}$ PBS, $0.5 \%$ Triton $\mathrm{X}-100$ by pelleting in a microfuge and resuspending, and bound radioactivity was determined by gamma counting. Data points are the mean of triplicate incubations. Specific binding $(\square)$ is the difference between binding of ${ }^{125} \mathrm{I}-\mathrm{mAb}$ in the absence of competing nonradioactive $\mathrm{mAb}(\triangle)$ and binding in the presence of competing nonradioactive $\mathrm{mAb}(\mathrm{O})$. 
any binding to AChRs solubilized from chick muscle (Table 1). This dearth of immunological cross-reactivity between AChRs of brain and muscle, which we have previously noted with polyclonal sera raised to chicken brain AChRs (Whiting and Lindstrom, 1986a), and have also observed with mAbs prepared to AChRs from rat brain (Whiting et al., 1987a, and unpublished observations), suggests that these AChRs have diverged substantially in their evolution from AChRs of muscle. This might be expected if the 2-subunit structure of these neuronal AChRs evolved by gene duplication from the subunit of the same primordial homopolymer AChR that evolved through repeated gene duplication along a different lineage of this gene family to produce the $\alpha_{2} \beta_{\gamma} \delta$ subunit structure of AChRs in muscle (Raftery et al., 1980; Noda et al., 1983b). The $\alpha_{2} \beta_{\gamma} \delta$ subunit structure of AChRs from muscle was well established by the time of primitive elasmobranchs and has changed little since, as indicated by the $80 \%$ sequence homology between the $\alpha$ subunits of AChRs from Torpedo electric organ and human muscle (Noda et al., $1983 a, b)$. By contrast, evolution of the neuronal nicotinic AChR lineage appears to have continued quite rapidly from the time of the cartilaginous fishes. We found no high-affinity nicotinic AChR in Torpedo brains. Brains of goldfish contain both AChRs with high affinity for $\alpha \mathrm{Bgt}$ and $\mathrm{mAbs}$ to the main immunogenic region (Henley et al., 1986a, b) and $\mathrm{AChRs}$ with high affinity for nicotine but no affinity for $\alpha \mathrm{Bgt}$ or $\mathrm{mAbs}$ to the main immunogenic region (Henley and Oswald, 1987; J. Henley, J. Lindstrom, and R. Oswald, unpublished observations). Brains of chickens contain AChRs with high affinity for nicotine, both of a type that binds $\mathrm{mAbs}$ to the main immunogenic region and of a type that does not (as shown here). Chicken brains also contain $\alpha$ Bgt binding components with subunits having sequence homology to AChR subunits (Conti-Tronconi et al., 1985), so this protein must also be a part of the AChR gene family. Chicken ciliary ganglion contains AChRs that bind mAbs to the main immunogenic region, but that have low affinity for nicotine (Halvorsen and Berg, 1986). Brains of rats have AChRs with high affinity for nicotine, but only of the subtype that does not significantly bind $\mathrm{mAbs}$ to the main immunogenic region (Whiting and Lindstrom, 1987a). Ganglionic-type AChRs from rats have low affinity for nicotine and do not bind $\mathrm{mAbs}$ to the main immunogenic region (Whiting et al., 1987b). High-affinity nicotinic AChRs can also be detected in detergent extracts of brains from cattle and humans, using mAbs prepared against AChRs from rat brain, and these AChRs also do not bind antibodies to the main immunogenic region (Whiting ct al., 1987a, and unpublished observations).

The possibility that additional AChR subtypes with high affinity for nicotine also exist but represent less than $10 \%$ of the total ${ }^{3} \mathrm{H}$-nicotine binding sites cannot be discounted. As discussed above, brain and ganglionic AChRs share several immunological determinants (Smith et al., 1985; Stollberg et al., 1986), but ganglionic AChRs have much lower affinity for cholinergic agonists (Halvorsen and Berg, 1986; Kemp and Morley, 1986) and differ from brain AChRs in their order of reaction with the affinity-labeling reagents MBTA and BAC (compare Leprince, 1983, with Whiting and Lindstrom, 1987b). Ganglionic AChRs are thus very similar to, but different from, brain AChRs, and can be considered another subtype of neuronal AChR. Low-stringency hybridization with cloned muscle AChR subunit cDNAs may identify several other AChR subunit homologs that may be components of neuronal nicotinic AChR subtypes (Goldman et al., 1986, 1987). The $\alpha \mathrm{Bgt}$ binding protein of brain and ganglia may also be a more distant relative in this extended family of neuronal AChRs (Conti-Tronconi et al., 1985). The function of this molecule is not known. In rat cervical ganglia (Brown and Fumagalli, 1977), rat PC12 cells (Patrick and Stallcup, 1977), chick ciliary ganglion neurons (Ravdin and Berg, 1979; Chiappinelli, 1983), rat coeruleus neurons (Egan and North, 1986), and cat carotid bodies (Gonzalez et al., 1986), this molecule clearly is not an ACh-regulated cation channel.

It is likely that the $75,000 M_{\mathrm{r}} \beta^{\prime}$ subunit of AChRs from chicken brain is homologus to the $79,000 \beta^{\prime}$ subunit of AChRs from rat brain because (1) $\mathrm{mAb} 286$ exhibits strong binding to both of these subunits (Whiting and Lindstrom, 1987a), (2) mAb 299, raised to AChRs from rat brain, also binds specifically to these 2 subunits (Whiting and Lindstrom, unpublished observations), (3) both these subunits are affinity-labeled with ${ }^{3} \mathrm{H}-\mathrm{MBTA}$, indicating that they contain the ACh binding site (Whiting and Lindstrom, 1987b), and (4) N-terminal amino acid sequence data indicate that the N-terminal of the $75,000 M_{\mathrm{r}} \beta^{\prime}$ subunit of AChR from chicken brain (unpublished observations) has $88 \%$ sequence homology with the $\mathrm{N}$-terminal of the $79,000 M_{\mathrm{r}} \beta^{\prime}$ subunit of AChR from rat brain (Whiting et al., $1987 \mathrm{c}$ ). The $59,000 M_{\mathrm{r}} \beta$ subunit of the $\alpha \beta$ AChR subtype from chicken brain is also affinity labeled with ${ }^{3} \mathrm{H}-\mathrm{MBTA}$ (Whiting and Lindstrom, 1987b), indicating that it is the ACh binding subunit of the $\alpha \beta$ AChR subtype.

It is quite striking that the 2 nicotinic AChR subtypes described here differ by 16,000 in the apparent molecular weight of their $\beta$ subunits (Fig. 3), which contain their ACh binding sites (Whiting and Lindstrom, 1987b), yet have the same high affinity for nicotine (Table 2). This could be explained if the amino acid sequence of the 2 subunits were quite similar except for the insertion of an additional domain in the $\beta^{\prime}$ subunits at a point away from the $A C h$ binding site. Muscarinic $M_{1}$ and $M_{2}$ AChRs offer an interesting comparison. cDNAs for these AChRs have been sequenced (Kubo et al., 1986a, b) and shown to be highly homologous except for one stretch of 127-152 amino acids that is unique to each AChR subtype. Similarly, the sequence of the $\beta^{\prime}$ subunit of nicotinic AChRs from rat brain (Goldman et al., 1987) shows extensive homology with that of $\alpha$ subunits of muscle AChRs in the region from the $\mathrm{N}$-terminus to about $\alpha 333$, but then exhibits little or no homology with the next 191 amino acids before a C-terminal region with some homology to $\alpha$ subunits. Examples of segmental homology between AChRs may predict the sequence relationship between the $\beta$ and $\beta^{\prime}$ subunits of the 2 AChR subtypes we have identified in chick brain.

The heterogeneity of neurotransmitter receptors is well known. As examples, the opioid receptor (Paterson et al., 1983), muscarinic AChR (Hoss and Ellis, 1985), dopamine receptor (Stoof and Kebabian, 1984), benzodiazapine receptor (Lo et al., 1982), and serotonin receptor (Peroutka and Snyder, 1979) all have several subtypes defined by their different pharmacological properties. Adrenergic receptor subtypes have been especially well-characterized in terms of pharmacology, structure, and function (Stiles et al., 1983; Lomasney et al., 1986). Heterogeneity of sodium channels of the nervous system has also been suggested electrophysiologically (Gundersen et al., 1983), immunochemically (Wollner and Catterall, 1985), and by molecular genetic techniques (Noda et al., 1986).

The role of the $2 \mathrm{AChR}$ subtypes in chicken brain is not yet known. Immunohistochemically, we have demonstratcd that in the Zebra finch brain (Podleski et al., 1986) and the chicken 
brain (Swanson et al., 1987), these AChR subtypes are located in different regions of the brain. As we have speculated above, the $\beta$ subunits of these AChRs may differ by a domain that is involved in neither ligand binding nor cation channel function, but rather in interaction with cytoskeletal or extracellular elements involved in AChR localization or turnover. Or this domain might be involved in alternate signaling by or regulation of these AChRs. It is possible that one of the subtypes is a postsynaptic $\mathrm{AChR}$, while the other is presynaptic, modulating the release of $\mathrm{ACh}$ or another neurotransmitter. In PC12 cells these AChRs modulate the release of ACh ( $T$. Rogers, personal communication), catecholamines (Mizobe and Livett, 1983), enkephalins (Eiden et al., 1984), and dopamine (Baizer and Weiner, 1985). Immunohistochemical techniques provide strong evidence that at least some of the AChRs in rat brain bound by mAb 270 are presynaptic (Swanson et al., 1987). mAbs will prove useful tools in localizing, identifying the cDNAs for, and determining the functional roles of neuronal $\mathrm{AChR}$ subtypes.

\section{References}

Aebersold, R. H., D. B. Teplow, L. E. Hood, and S. B. H. Kent (1986) Electroblotting onto activated glass: High efficiency preparation of proteins from analytical SDS-polyacrylamide gels for direct sequence analysis. J. Biol. Chem. 261: 4229-4238.

Baizer, L., and N. Weiner (1985) Nerve growth factor treatment enhances nicotine-stimulated dopamine release and increases in cyclic adenosine $3^{\prime}: 5^{\prime}$ monophosphate levels in PC12 cell cultures. J. Neurosci. 5: 1176-1179.

Boulter, J., K. Evans, D. Goldman, G. Martin, D. Treco, S. Heinemann, and J. Patrick (1986) Isolation of a cDNA clone coding for a possible neuronal nicotinic acetylcholine receptor alpha subunit. Nature 319 : 368-374.

Brisson, A., and N. Unwin (1984) Tubular crystals of acetylcholine receptor. J. Cell Biol. 99: 1202-1211.

Brown, D. A., and L. Fumigalli (1977) Dissociation of $\alpha$ bungarotoxin binding and receptor block in the rat superior cervial ganglion. Brain Res. 129: 165-168.

Carbonetto, S. T., D. M. Fambrough, and K. J. Muller (1978) Nonequivalence of $\alpha$ bungarotoxin receptors and acetylcholine receptors in chick sympathetic neurons. Proc. Natl. Acad. Sci. USA 75: 10161020.

Chiappinelli, V. A. (1983) Kappa toxin: A probe for neuronal nicotinic receptor in the avian ciliary ganglion. Brain Res. 277: 9-21.

Chiappinelli, V. A. (1985) Actions of snake venom toxins on neuronal nicotinic receptors and other neuronal receptors. Pharmacol. Ther. 31: 1-32.

Chiappinelli, V. A., K. M. Wolf, J. A. De Bin, and I. L. Holt (1987) Kappa-flavitoxin: Isolation of a new neuronal nicotinic receptor antagonist that is structurally related to kappa-bungarotoxin. Brain Res. 402: $21-29$.

Conti-Tronconi, B. M., S. M. J. Dunn, E. A. Barnard, J. O. Dolly, F. A. Lai, N. Ray, and M. A. Raftery (1985) Brain and muscle nicotinic acetylcholine receptors are different but homologous proteins. Proc. Natl. Acad. Sci. USA 82: 5208-5212.

Egan, T. M., and R. A. North (1986) Actions of acetylcholine and nicotine on rat coeruleus neurons in vitro. Neuroscience 19:565-571.

Eiden, L. E., P. Giraud, J. R. Dave, A. J. Hotchkiss, and H. U. Affolter (1984) Nicotinic receptor stimulation activates enkephalin release and biosynthesis in adrenal chromaffin cells. Nature 312: 661-663.

Freeman, J. A., J. T. Schmidt, and R. E. Oswald (1980) Effect of $\alpha$ bungarotoxin in retinotectal synaptic transmission in goldfish and toad. Neuroscience 5: 929-942.

Goldman, D., D. Simmons, L. W. Swanson, J. Patrick, and S. Heinemann (1986) Mapping of brain areas expressing RNA homologous to two different acetylcholine receptor $\alpha$-subunit cDNAs. Proc. Natl. Acad. Sci. USA 83: 4076-4080.

Goldman, D., E. Deneris, W. Luyten, A. Kochhar, J. Patrick, and S. Heinemann (1987) Members of a nicotinic acetylcholine receptor gene family are expressed in different regions of the mammalian central nervous system. Cell 48: 965-973.

Gonzalez, C., A. Obeso, B. Dinger, and S. Fidone (1986) Non-identity of nicotinic receptors and $\alpha$ bungarotoxin binding sites in cat carotid body. Soc. Neurosci. Abstr. 11: 67.

Gullick, W., and J. Lindstrom (1983) Mapping the binding of monoclonal antibodies to the acetylcholine receptor from Torpedo californica. Biochemistry 22: 3312 .

Gundersen, C. B., R. Miledi, and I. Parker (1983) Voltage operated channels induced by foreign messenger RNA in Xenopus oocytes. Proc. R. Soc. [Biol.] 220: 131-140.

Halvorsen, S. W., and D. K. Berg (1986) Identification of a nicotinic acetylcholine receptor on neurons using an $\alpha$-ncurotoxin that blocks receptor function. J. Neurosci. 6: 3405-3412.

Halvorsen, S. W., and D. K. Berg (1987) Affinity labeling of neuronal acetylcholine receptors with an $\alpha$-neurotoxin that blocks receptor function. J. Neurosci. 7: 2547-2555.

Henley, J., and R. Oswald (1987) Two distinct (-)nicotine binding sites in goldfish brain. J. Biol. Chem. 262: 6691-6698.

Henley, J., J. Lindstrom, and R. Oswald (1986a) Acetylcholine receptor synthesis in retina and transport to optic tectum in goldfish. Science 232: 1627-1629.

Hènley, J., M. Mynlieff, J. Lindstrom, and R. Oswald (1986b) Interaction of monoclonal antibodies to electroplaque acetylcholine receptors with the $\alpha$ bungarotoxin binding site of goldfish brain. Brain Res. 364: 405-408.

Hochschwender, S., L. Langeberg, D. Schneider, and J. Lindstrom (1985) Production of rat $\times$ mouse hybridomas for the study of the nicotinic acetylcholine receptor. In Hybridoma Technology in the Biosciences and Medicine, T. A. Springer, ed., pp. 223-238, Plenum, New York.

Hoss, W., and J. Ellis (1985) Muscarinic receptor subtypes in the central nervous system. In International Review of Neurobiology, vol. 26, J. Smithies and R. Bradley, eds., pp. 151-200, Academic, New York.

Jacob, M. H., and D. K. Berg (1983) The ultrastructural localization of $\alpha$ bungarotoxin binding sites in relation to synapses on chick ciliary ganglion neurons. J. Neurosci. 3: 260-271.

Jacob, M. H., D. K. Berg, and J. M. Lindstrom (1984) Shared antigenic determinant between the Electrophorus acetylcholine receptor and a synaptic component on chicken ciliary ganglion neurons. Proc. Natl. Acad. Sci. USA 81: 3223-3227.

Jacob, M. H., J. M. Lindstrom, and D. K. Berg (1986) Surface and intracellular distribution of a putative neuronal nicotinic acetylcholine receptor. J. Cell Biol. 103: 205-214.

Kao, P. N., and A. Karlin (1986) Acetylcholine receptor binding site contains a disulfide crosslink between adjacent half cystinyl residues. J. Biol. Chem. 261: 8085-8088.

Kao, P. N., A. J. Swork, K. K. J. Kaldany, M. L. Silver, J. Wideman, S. Stein, and A. Karlin (1984) Identification of the $\alpha$ subunit halfcystine specifically labeled by an affinity reagent for the acetylcholine receptor binding site. J. Biol. Chem. 259: 11662-11665.

Karten, H. J., K. T. Keyser, P. J. Whiting, and J. M. Lindstrom (1987) Nicotinic acetylcholine receptors in developing and adult avian retina: An immunohistochemical study. Abstract presented at Meeting of the Association for Research in Vision and Opthalmology.

Kemp, G., and B. J. Morley (1986) Ganglionic AChRs and high affinity nicotinic binding sites are not equivalent. FEBS Lett. 205: 265-268.

Kouvelas, E. D., M. A. Dichter, and L. A. Greene (1978) Sympathetic neurons develop receptors for $\alpha$ bungarotoxin in vitro, but toxin does not block nicotinic receptors. Brain Res. 154: 83-93.

Kubalek, E., S. Ralston, J. Lindstrom, and H. Unwin (1987) Location of $\alpha$ subunits within the acetylcholine receptor: Analysis of tubular crystals from Torpedo marmorata. J. Cell Biol. 105: 9-18.

Kubo, T., K. Fukuda, A. Mikami, A. Maeda, H. Takahashi, M. Mishina, T. Haga, K. Haga, A. Ichiyama, K. Kangawa, M. Kojima, H. Matsuo, T. Hirose, and S. Numa (1986a) Cloning, sequencing and expression of complementary DNA encoding the muscarinic acetylcholine receptor. Nature 323: 411-416.

Kubo, T., A. Maeda, K. Sugimoto, I. Akiba, A. Mikami, H. Takahashi, T. Haga, K. Haga, A. Ichiyama, K. Kangawa, H. Matsuo, T. Hirosc, and S. Numa (1986b) Primary structure of porcine cardiac muscarinic acetylcholine receptor deduced from the cDNA sequence. FEBS Lett. 209: 367-372.

Leprince, P. (1983) Chemical modification of the nicotinic cholingeric receptor of PC-12 nerve cell. Biochemistry 22: 5551-5556.

Lindstrom, J. M. (1984) Nicotinic acetylcholine receptors: Use of monoclonal antibodies to study synthesis, structure, function, and autoimmune response. In Monoclonal and Anti-Idiotypic Antibodies: Probes for Receptor Structure and Function, J. C. Venter, C. M. Fraser, and J. M. Lindstrom, eds., pp. 21-57, Liss, New York. 
axonal transport, enzyme histochemistry, and light microscopic analysis. In Tracing Neural Connections with Horseradish Peroxidase, $\mathbf{M}$. M. Mesulam, ed., pp. 1-151, Wiley, Chichester, UK.

Nakano, K., M. Kohno, Y. Hasegawa, and A. Tokushige (1985) Cortical and brain stem afferents to the ventral thalamic nuclei of the cat demonstrated by retrograde axonal transport of horseradish peroxidase. J. Comp. Neurol. 231: 102-120.

Narkiewicz, O., and S. Brutkowski (1967) The organization of projections from the thalamic mediodorsal nucleus to the prefrontal cortex of the dog. J. Comp. Neurol. 129: 361-374.

Oka, H. (1980) Organization of the cortico-caudate projections. A horseradish peroxidase study in the cat. Exp. Brain Res. 40:203-208.

Oka, H., and K. Jinnai (1978) Common projection of the motor cortex to the caudate nucleus and the cerebellum. Exp. Brain Res. 31: 3142.

Rausell, E., and C. Avendaño (1985) Thalamocortical neurons projecting to superficial and deep layers in parietal, frontal, and prefrontal regions in the cat. Brain Res. 347: 159-165.

Royce, G. J. (1982) Laminar origin of cortical neurons which project upon the caudate nucleus: A horseradish peroxidase investigation in the cat. J. Comp. Neurol. 205: 8-29.

Royce, G. J. (1983) Cortical neurons with collateral projections to both the caudate nucleus and the centromedian-parafascicular thalamic complex: A fluorescent retrograde double labeling study in the cat. Exp. Brain Res. 50: 157-165.

Schwab, M., Y. Agid, L. Glowinski, and H. Thoenen (1977) Retrograde axonal transport of ${ }^{125} \mathrm{I}$-tetanus toxin as a tool for tracing fiber connections in the central nervous system; connections of the rostral part of the rat neostriatum. Brain Res. 126: 211-224.
Shook, B. L., B. P. Abramson, and L. M. Chalupa (1984) An analysis of the transport of WGA-HRP in the cat's visual system. J. Neurosci. Methods 11: 65-77.

Stanton, G. B., D. Tanaka, Jr., S. T. Sakai, and O. I. Weeks (1986) Thalamic afferents to cytoarchitectonic subdivisions of area 6 on the anterior sigmoid gyrus of the dog: A retrograde and anterograde tracing study. J. Comp. Neurol. 252: 446-467.

Tanaka, D., Jr. (1987) Neostriatal projections from cytoarchitectonically defined gyri in the prefrontal cortex of the dog. J. Comp. Neurol. 261: 48-73.

Tanaka, D., Jr., T. Górska, and K. Dutkiewicz (1979) Differential projections to the neostriatum from the arm areas of the primary and supplementary motor cortices in the dog. Brain Res. 172: 150-154.

Tanaka, D., Jr., T. Górska, and K. Dutkiewicz (1981) Corticostriate projections from the primary motor cortex in the dog. Brain Res. 209: 287-303.

Tanaka, D., Jr., S. T. Sakai, and T. Górska (1983) Corticothalamic projections from postcruciate area 4 in the dog. J. Comp. Neurol. 214: $17-31$.

Veening, J. G., F. M. Cornelissen, and P. A. J. M. Lieven (1980) The topical organization of the afferents to the caudatoputamen of the rat. A horseradish peroxidase study. Neuroscience 5: 1253-1268.

Velayos, J. L., and F. Reinoso-Suárez (1985) Prosencephalic afferents to the mediodorsal thalamic nucleus. J. Comp. Neurol. 242: 161181

Wise, S. P., and E. G. Jones (1977) Cells of origin and terminal distribution of descending projections of the rat somatic sensory cortex. J. Comp. Neurol. 175: 129-158. 